\title{
Proceedings, 115th Annual Meeting Medical Library Association, Inc. Austin, TX May 15-20, 2015EC
}

Nicole Mitchell, MLIS, MA

See end of article for author's affiliation.

\section{CONTENTS}

Introduction $\ldots \ldots \ldots \ldots \ldots \ldots \ldots \ldots$ E1

Welcome to MLA'15 . . . . . . . . . . . E1

MLA Presidential Address: Linda Walton, AHIP

(Plenary Session I) . . . . . . . . . . . . . E3

Other Plenary Sessions ............. E6

Awards Ceremony and Luncheon ......... E7

Business Meeting 1 . . . . . . . . . . . . E15

Business Meeting 2, Presidential Inaugural Address:

Michelle Kraft, AHIP, and MLA '16

Invitation . . . . . . . . . . . . . . . E24

Section Programming . . . . . . . . . . . . E29

Poster Sessions . . . . . . . . . . . . . . . . . E29

Other Meetings and Events . . . . . . . . . . . E29

Open Forums . . . . . . . . . . . . . . . . . E30

National Library of Medicine Update . . . . . . E30

Legislative Update . . . . . . . . . . . . . . . . . E31

Other Special Events and Receptions . . . . . . . E31

Sunrise Seminars . . . . . . . . . . . . . . . E31

Technology Showcases . . . . . . . . . . . . . E31

Continuing Education Courses . . . . . . . E31

Resources and Services ... . . . . . . . . . . E33

\section{INTRODUCTION}

The Medical Library Association (MLA) held its 115th annual meeting in Austin, Texas, May 15-20, 2015, at the Austin Convention Center and Austin Hilton. The meeting theme was "Librarians without Limits." Total attendance for the meeting was 1,817, with 283 participating in continuing education courses. Additional meeting content-including the meeting program and various electronic presentations from the business meetings, plenary

Supplemental appendixes with the full abstracts of papers and posters presented at MLA ' 15 are available with the online version of this journal.
DOI: http://dx.doi.org/10.3163/1536-5050.103.1.E1

sessions, poster sessions, and section programs - can be accessed by all meeting registrants via the MLA '15 website.

\section{WELCOME}

\section{Sunday, May 17, 2015}

President Linda Walton, AHIP, welcomed attendees to Austin, Texas for MLA '15, noting that the theme, "Librarians without Limits," pays tribute to the free and creative spirit that inhabits Austin and reminds the audience of the unlimited opportunities to compose and fine-tune their professional goals that will direct our present and future roles and services. She urged everyone to take the time to nurture relationships with colleagues and friends and to take advantage of the professional development opportunities with timely and relevant continuing education (CE) courses. President Walton encouraged attendees to explore Austin and to join in the MLA in Monte Carlo closing event.

President Walton then introduced Andrew P Dillon, dean, School of Information, University of Texas-Austin, who welcomed attendees to Austin. She then introduced Stewart Brower, AHIP, chair, South Central Chapter, and director, Schusterman Library, University of Oklahoma-Tulsa, who brought greetings from the chapter.

President Walton then returned to the podium to introduce the 2015 National Program Committee and the 2015 Local Assistance Committee: Sandra I. Martin, AHIP, cochair, 2015 National Program Committee, and director, Shiffman Medical Library, Wayne State University, Detroit, MI; Jonquil D. Feldman, AHIP, cochair, 2015 National Program Committee, and director, Library Services, Briscoe Library, University of Texas Health Science Center- 
San Antonio; Catherine Pepper, chair, 2015 Local Assistance Committee, and assistant professor and coordinator, Library Services, Medical Sciences Library, Texas A\&M University-Round Rock; and Katie Prentice, AHIP, chair, Volunteer Subcommittee, and associate director of user experience and assessment, Schusterman Library, University of Oklahoma-Tulsa.

Sandra I. Martin, AHIP, and Jonquil D. Feldman, AHIP: Good morning everyone. On behalf of the 2015 National Program Committee, we would like to welcome you to Austin. Linda has told you so much of what is in store, but we'd like to share with you what we had in mind when we chose the theme for this meeting: Librarians without Limits. Librarians follow traditional methods to organize and ensure access to information, yet we do not confine ourselves to the traditional. We connect with users in unconventional ways, moving well beyond our comfort zones.

We are involved in and sometimes lead the way in bioinformatics, e-science, open access, and data mining. Some of us are embedded in departments, and many of us teach and consult in meeting rooms and offices beyond the library walls. Our expertise, training, and innovative nature have taken us into new roles well beyond what is typically thought to be library work.

Much like the talented indie stars who perform at Austin City Limits, librarians are independent thinkers and stars. In the next three days, we'll have the opportunity to share, to learn, and to discuss how librarians are reaching beyond the conventional and redefining how we work and proceed. Let's face it: the sky's the limit. And by the way, how sweet is it that our speaker this morning has had firsthand experience with breaking barriers and setting new limits?

This meeting has been three years in planning, and we are really excited and relieved that it is finally here. We would like to invite everyone who contributed papers, posters, or lightning talks abstracts to stand as well as those who are panelists, moderators, and continuing education instructors.

We would also like to recognize the members of the 2015 National Program Committee (NPC), members who coordinated every aspect of the program: selection of plenary speakers, continuing education, posters, papers, publicity, fundraising, and social media. Those members are: Sandra G. Franklin, AHIP; Stephanie Fulton, AHIP; Gail
Kouame; Rosalind K. Lett; Merinda McLure, AHIP; William Olmstadt, AHIP; Catherine Pepper; Katie Prentice, AHIP; Leslie C. Schick; Michael E. Simmons; and Linda Walton, AHIP, MLA president. Ladies and gentleman, your 2015 NPC.

We also thank Ray Naegele, Carla J. Funk, CAE, Kevin Baliozian, and the staff at MLA, meeting planners Tina Vickery and Mary Oberman, and exhibitors and sponsors who support our work and make it possible to host our speakers and share our program. Please make time to visit them and the exhibit hall.

Next, I would like to invite Cathy Pepper and Katie Prentice to share a few words about the out-ofthis-world Local Assistance Committee.

Catherine Pepper: Good morning. Katie, it seems like it was only a year ago that we were standing up before everybody in Chicago to invite them to Austin.

Katie Prentice, AHIP: Cathy, that's because it was a year ago when we were in Chicago talking about Austin.

\section{Catherine Pepper: Isn't Austin great?}

Katie Prentice: Yes, it is. It is, indeed, limitless fun.

Catherine Pepper: We know you're here for the meeting, but get ready for bats, music, food, and fun. In fact, hospitality is offering bat meet-ups, weather permitting, for groups to walk together to watch the bats fly each evening. We've also heard that some really cute bats have migrated to the MLA gift shop, so check that out.

Katie Prentice: Purchase one. Take one home with you for a scholarship. Hopefully, outside the natural bat will improve a bit and the El Nino weather, which is a bit rainy, will subside. Right outside you have the hike-and-bike trail. A little further away is Zilker Park and the Barton Springs pool and the Barton Creek trail. There are also opportunities to see local libraries, if you're inclined, for a scholarly visit while you're here.

Catherine Pepper: While here in Austin, you may see some very interesting sights. Keep in mind that one of the mottos is "Keep Austin Weird." But perhaps during all of this this morning, you forgot to take notes on these wonderful activities. But don't fret. Visit the hospitality booth downstairs for more information for help planning your fun without limits. 
Katie Prentice: Speaking of the hospitality booth, your 2015 Local Assistance Committee has been really busy this past year getting ready for this moment. them.

Catherine Pepper: Let's go ahead and recognize

Katie Prentice: Okay. Chair of the hospitality booth is Darlene Ennis, and her subcommittee members are Lindsay Rainey; Lauren Wojcik; Barbara Cosart, AHIP; Sandra Teft; Jack Perry; Laura Fry; and Nicole Paris. Derek Holland is the chair of library tours and other sightseeing tours. Derek's put together an awesome guide to all the things you can see here in Austin and that can be found at the hospitality booth.

And Lisa Wong is our blog chair. So she's been keeping you up to date on up-to-the-minute happenings with the blog. Our chair of publicity and promotion is Michele Whitehead. We can thank her for all the great newsletter articles. And our terrific restaurant guide was done by Steve Self, AHIP. And Steve and Margaret Peloquin, AHIP, are cochairs for the Continuing Education Subcommittee. Thank you, Steve and Margaret, for hosting the off-site courses at Austin Community College.

Catherine Pepper: And you, Miss Katie Prentice, are our chair of volunteer assistance, with members Lindsay Rainey, Margaret Peloquin, and Ellen Todd Hanks, AHIP. Thank you very much.

President Walton returned to the podium to recognize and thank all the vendors who generously contributed to the meeting's success.

The chairs of the National Program Committee then introduced President Walton who gave her presidential address.

\section{MLA PRESIDENTIAL ADDRESS: LINDA WALTON, AHIP (PLENARY SESSION I)}

Linda Walton, AHIP: Good morning. As you can imagine, given the number of changes we've seen throughout the year, this has indeed been an interesting year for the Medical Library Association (MLA) as members. My address today is not so much what I have done, but what our board of directors and members, along with help from headquarters staff, have accomplished this year.

As members, you elect the Board of Directors and the president. We are the stewards of your organization and accountable to you. We have four primary responsibilities to our members:

governance, strategy, finance, and ambassadorship. Let's see how we did this past year.

Through governance, we enable execution of the association's priorities, programs, and strategic plan by hiring the executive director and by setting up the right committees and task forces. As you are aware, Carla J. Funk, CAE, retired and the board was tasked with hiring a new executive director. The Search Committee, under the leadership of Past President Dixie A. Jones, AHIP, worked with Tufts \& Associates to identify and interview qualified candidates who could serve as our new executive director.

The search firm interviewed members of MLA, the Board of Directors, and headquarters staff to develop a profile of what we wanted in a new executive director of MLA. Kevin Baliozian, do you want to stand up?

Kevin will be giving the headquarters update at the business meeting this afternoon at three o'clock in this room. I encourage you to attend this session, as Kevin would like to spend some time engaging in Q\&A with our members. He's creative and lively, has an overflowing reservoir of energy, and likes to get shit done. I can assure you that it will be a fun and productive business meeting.

I'd also like to give a special shout out to Dixie for all the work she did keeping the rest of us on track during the search.

At our first in-person board meeting with Kevin, we engaged in team-building exercises as we worked to establish a new strategic plan for MLA. To keep us on track, Kevin and I hold biweekly calls. In alternating weeks, we have established conference calls with the executive committee. We also added on an additional all-board virtual meeting for the year, so now the board meets three times in person and two times a year virtually. Although it's still too early to say, I think this approach to governance will lead to a more active and inclusive board.

I'm sure you've also noticed that we're working on improving communication with our membership so that you also have a greater say in MLA's priorities and direction. The new blog, Full Speed Ahead, has been a hit with members, and we've appreciated receiving all your feedback and comments, so please continue to do that. 
MLA appoints six officials. Along with Kevin this year, the board also approved Diane Cooper, AHIP, as the Journal of the Medical Library Association (JMLA) editor in chief, and her term began with the January 2015 issue. The board approved Cheryl Rowan as the new MLA News editor, and her term will begin with the June/July 2015 issue. Again, look for changes and enhanced communications.

In addition to three task forces, this year the board established one committee: the Ad Hoc Committee to Review Core Clinical Journals. A joint committee with the National Library of Medicine (NLM), the committee is charged with producing a new core clinical journal list for the creation of a revised PubMed filter. It will include journals that are of immediate interest to practicing health care individuals and journals supporting hospital librarians in their efforts to provide access to the essential biomedical literature for their physicians and health care providers. Yay!

Three task forces-focusing on education, research, and strategic priorities-have been established. Two of the three open forums being held at this meeting, "Redesigning MLA: Sections and Special Interest Groups (SIGs)" and "Revitalizing the Professional Competencies for Lifelong Learning," are being hosted by these new task forces on Monday from 2:00 p.m. to 3:00 p.m. We think they'll influence the direction of our strategic planning process, and I strongly encourage you to attend the forums if you can. And let me quickly mention that the third forum, at the same time, is "Around the World in Sixty Minutes" and is sponsored by the International Cooperation Section.

Through strategy, the board sets direction for the organization so that it falls in line with our vision, values, and mission. At our February 25 meeting, the board created a new strategic plan. The plan includes four components: what MLA does, new professionals, education, and MLA technology. I won't go into the details at this time as Michelle Kraft, AHIP, will talk about the strategic plan and its goals at her inaugural address on Tuesday at 9:00 a.m.

The new strategic plan has been designed to strengthen our association so that it remains relevant, vital, and strategically positioned as we move forward. To clarify, MLA still has five programmatic areas that we focus on, including community, professional development, advocacy, publications, and partnerships.
The board approves the budget, and we are accountable to you to maintain fiscal responsibility. For 2015, MLA successfully met the fiscal challenges of the recession and our shrinking membership. In the fall, the board approved the 2015 budget and business plan. We also approved an extraordinary budget request to hire a search firm for the new executive director, with funding coming from the association's healthy reserves. And believe me, this was money well spent. Chris Shaffer, AHIP, our treasurer, will go into more detail regarding the association's budget at this afternoon's business meeting.

The board serves as ambassadors for the profession in several ways. Some examples include attending chapter meetings, visiting congressional leaders, attending other professional meetings, and honoring leaders. I'll highlight just a few activities from the last year.

This year, two of our most honored leaders retired. Carla Funk, MLA's former executive director, retired after twenty-two years and eleven months. Her contributions to the association were tremendous. Two accomplishments that I'm especially proud of has been our expansion of MLA's global face and the establishment of the Carla J. Funk Governmental Relations Award.

Donald A. B. Lindbergh, director of the National Library of Medicine (NLM), also retired after thirtyone years of leading the world's largest medical library. Speaking on behalf of the health sciences librarians and MLA at his retirement reception, I thanked Donald for the new opportunities he brought to our profession. I said, from end-user searching to bioinformatics to disaster preparedness, he led the way for health sciences librarians to develop and expand our expertise through the use of technology. And he actually thanked me and everything. It was very exciting.

On June 25, I presented Senator Tom Harkin, a Democrat from Iowa, with honorary MLA membership at the senator's constituent breakfast in Washington, DC. Accompanying me was Past President Gerald J. Perry, AHIP. Senator Harkin announced his retirement after serving thirty years in the US Senate and ten years in the US House of Representatives. The award recognizes and thanks Senator Harkin for his staunch commitment and leadership to bolstering funding that supports the programs and services of the National Library of Medicine and the National Institutes of Health. 
Dave Moore, Association of American Medical Colleges (AAMC) senior director of government relations, was presented with a joint resolution from MLA and the Association of Academic Health Sciences Libraries (AAHSL). We thanked him for thirty years of outstanding leadership and service to the AAMC and members of the ad hoc group for medical research, including MLA and AAHSL, which has made a difference and strengthened the message that all our organizations bring to the members of Congress on behalf of our nation's biomedical research and education committees. And I don't know who that person is slouching there in the back of the photo. I tried to cut it.

I participated along with other MLA members in three international conferences. This year, the International Federation of Library Associations and Institutions (IFLA) meeting was held in Lyon, France. Judy Consales and I presented a paper on new and changing roles for health sciences librarians. I was invited by one of our international members to present an overview of MLA at the Third Seminar of Librarians and Medical Information held in Mexico City. Other MLA members presenting at this meeting included Susan Fowler and Myriam MartinezBanuelos.

And finally, as a result of that presentation, I met a medical librarian from Columbia who invited me to present on the profile of the US health sciences librarian at a conference being held in Bogota. My session was videotaped with the help of Amy Blevins, and they'll watch that at the end of May-I think it's May 28-and then I'll Skype in for a Q\&A session. So that should be fun.

Members of the board make every attempt to attend chapter meetings. In fact, attending the meetings is one of the highlights of the fall. This year, I was fortunate to attend the Midwest Chapter, Southern Chapter, North Atlantic Health Sciences Libraries, and New York-New Jersey Chapter meetings. I was sorry to miss the Quint Meeting as well as a few other meetings, but Dixie and Michelle were able to attend so the board was well represented. As you can see, the board has been busy governing, strategizing, budgeting, and promoting the association.

Now, I'd like to take a few minutes to thank members and headquarters staff for all the work that you do to support our members and to ensure that MLA's first program areas-including professional development, community, advocacy, publications, and partnerships - remain robust and successful.

One of the many things that makes MLA such a great organization is to be part of a sense of a community. While a new member and some of us older members might find MLA overwhelming, experience has shown that the best thing to do is jump right in and become active. Becoming involved gives you opportunities to contribute, meet new colleagues, make new friends, and learn. MLA's community consists of sections, committees, chapters, and special interest groups. Last year, I was so happy that everyone who completed a committee appointment application was given a spot.

I personally thank all of you for volunteering and making my presidency such a wonderful and fulfilling experience.

Professional development is a huge part of MLA. Thank you to everyone who contributes to the continuing education of our members and to those who attend the various programs. I especially want to thank those who organized and participated in the planning of this meeting, arranging speakers, coordinating papers and posters, selecting and presenting continuing education classes, and mentoring. We're all better informed health sciences librarians after experiencing the annual meeting.

While there are many things going on with advocacy, there were two initiatives this year that I think deserve special recognition. First, comments and recommendations made to the Accreditation Council for Pharmacy Education, comments made by MLA, the Pharmacy and Drug Information Section of MLA, AAHSL, and the Association of College and Research Libraries Health Sciences Interest Group were incorporated into the 2016 standards and recognize that having access to librarian expertise and resources is an important component of pharmacy education. So I think we need a round of applause for that success. I know those individuals worked really hard to make that happen, and we're very excited for them.

Second, MLA committees and sections wrote a fifteen-page document that includes comments and recommendations on the importance of NLM support to the health sciences library community, health professionals, research, and the public in their response to the National Institutes of Health (NIH) request for information soliciting input into the deliberations of the Advisory Committee to the NIH 
Director Working Group on the National Library of Medicine.

Both of these initiatives involved partnering with colleagues and have an impact on the expertise of health sciences librarians and health care. So again, thank you.

Thanks to so many of you who write, edit, blog, and tweet. Again, you play a vital role in the success of the organization and the profession by

documenting your research and your ideas.

This year, we signed a new bilateral agreement with the Mexican Library Association, and we renewed our agreement with the Canadian Health Libraries Association/Association des bibliothéques de la santé du Canada. We're sorry to hear of the earthquakes in Nepal, and we keep the citizens of Nepal and our colleagues there in our hearts and minds as they recover from this tragedy.

Many of the National Network of Libraries of Medicine (NN/LM) sponsor the hosting of MLA webinars, provide instructions, and support our members in many other ways, so we appreciate all these different ways of partnering.

A very special note that Mary Langman, director of information issues and policy at MLA headquarters, received the 2014 Cornerstone Award, AAHSL's highest honor. We all thank Mary for her hard work, boundless energy, and commitment to information issues and policy. Congratulations, Mary.

So now just a couple of thank-yous. First, a special thank you to my awesome staff at the Hardin Library for the Health Sciences, who were patient

throughout the year regardless of my most recent crisis or drama, not to mention my absence. A very special thank you to Janna Lawrence, AHIP, deputy director, for keeping things going at Hardin. And a shout out to the university librarian, John Culshaw, for supporting me and encouraging me throughout my presidency.

Being president of MLA would not be possible without the wonderful support of family and friends. So thanks to my children, Matt and Claire, and a special thank you to my boyfriend, Randy Stark, who traveled with me on several of my trips and acted as my personal secretary as I got ready for meetings. Of course I always managed to forget something, and he would eagerly bring it to me whenever I'd call, whether it was a document, my meds, or my head. Good thing it's attached.
I also want to thank all of those who encouraged, mentored, and supported me along the way in my career, including James Shedlock, AHIP, FMLA; Wayne J. Peay, FMLA; Elaine Russo Martin; Angela Ruffin; Dixie Jones; and Judy Consales, to name a few.

And now, for the final item on today's agenda, on behalf of the association and the Board of Directors, I want to take this opportunity to express our thanks to the MLA headquarters staff. The staff works very hard, day in and day out, to support the association and our members. Over the years, I've come to know many of them and have relied on their expertise, knowledge, commitment, finesse, and even their sense of humor. They deal with many diverse and unique situations. They're always ready, willing, and able to work with the MLA president and other board members in our efforts on behalf of the membership and the profession. Will members who are present please stand and be recognized?

President Walton concluded her address and urged attendees to attend the John P. McGovern Award Lecture delivered by Mae Jemison, founder and president of the Jemison Group, a general practice physician, and former NASA astronaut, who is currently leading the 100 Year Starship in an initiative to ensure the capability for human space travel to another start is made possible within the next 100 years.

\section{OTHER PLENARY SESSIONS}

All plenary session videos and slides are available online to MLA '15 registrants from the MLA '15 website. See www.eventscribe.com/2015/MLA for more information about all speakers and sessions.

\section{Sunday, May 17: The John P. McGovern Award Lecture}

Introduction: Sandra I. Martin, AHIP, cochair, 2015 National Program Committee, and director, Shiffman Medical Library, Wayne State University, Detroit, MI

Radical Leaps, Discontinuities, Uncertainty, Fear, and Society's Future: Mae C. Jemison, astronaut and physician, founder and president of the Jemison Group, current leader of the 100 Year Starship (100YSS) 


\section{Monday, May 18: The Janet Doe Lecture}

Introduction: Margaret Moylan Bandy, AHIP, FMLA, medical librarian and manager, Library and Knowledge Services, Exempla Saint Joseph Hospital, Denver, CO

In Their Own Words: Oral Histories of MLA Past Presidents: Barbara A. Epstein, AHIP, director, Health Sciences Library System, University of Pittsburgh, and director, Middle Atlantic Region, National Network of Libraries of Medicine (NN/LM MAR), Pittsburgh, PA

\section{Wednesday, May 20: The Joseph Leiter NLM/ MLA Lecture}

Introduction: Christine Whitaker, chair, Joseph Leiter NLM/MLA Lectureship Committee, and collection development librarian, School of Medicine Library, University of South Carolina-Columbia

Speaker: Ann McKee, School of Medicine, Boston University, Boston, MA

\section{Wednesday, May 20: Plenary Session 4}

Introduction: Jonquil D. Feldman, AHIP, cochair, 2015 National Program Committee, and director, Library Services, Briscoe Library, University of Texas Health Science Center-San Antonio

Web of Opportunity or Web of Confusion? The Role of Skills in Internet Use: Eszter Hargittai, Delaney

Family Professor, Communication Studies Department, Faculty Associate of the Institute for Policy Research, Northwestern University

\section{AWARDS CEREMONY AND LUNCHEON}

The Awards Ceremony and Luncheon was held on Monday, May 18, from noon-1:30 p.m. President Linda Walton, AHIP, welcomed attendees and award recipients.

Linda Walton, AHIP: Good afternoon! Today, we honor our colleagues who have made outstanding contributions to the profession and the association. The names of this year's recipients are listed on the awards program for your reference. I would like to take this opportunity to acknowledge the 2015 MLA section and chapter award winners, who are listed in the brochure insert. MLA sections and chapters annually award and honor their members for outstanding work within their sections or chapters. Would all section and chapter award winners in the audience today please stand to be recognized? Thank you.

Two thousand fifteen was an exceptional year for members of the health information profession. We have members from across the country and world who have excelled in every facet of librarianship, and we are pleased to present them and recognize their accomplishments.

Today, I thank Melanie Norton, AHIP, chair of the Awards Committee, and Carrie L. Iwema, AHIP, chair of the Grants and Scholarships Committee, and all jury members for your time and effort. Melanie, Carrie, and members of the juries seated in the audience, would you please stand? Thank you.

The MLA Rising Stars program identifies MLA members who have the interest, initiative, and potential to provide leadership to MLA at a national level. The program matches each Rising Star with a mentor in a year-long leadership development curriculum. The curriculum includes experiential learning, personal mentoring, and group instruction via online seminars. On Friday, May 15, the Rising Stars presented their projects to the MLA Board of Directors. President Walton briefly described each Rising Star's project: Roy Eugene Brown, AHIP, Tompkins-McCaw Library for the Health Sciences, Virginia Commonwealth University-Richmond, worked with Helen-Ann Brown Epstein, AHIP, and the Hospital Libraries Section leadership team on the VALUES@ Initiative; Lisa Huang, Central Park Campus Library, Collin College, McKinney, TX, worked with Laurie L. Thompson, AHIP, FMLA, on the MLA News Feasibility Study; April Schweikhard, Schusterman Library, University of Oklahoma-Tulsa, worked with Angela Dixon, AHIP, on Chapter Council roundtables; and Debra Werner, John Crerar Library, University of Chicago, Chicago, IL, worked with Linne' Girouard and Linda Hasman on the Public Policy Toolkit for Members, Sections, and Chapters.

President Walton announced that Ann McKee, School of Medicine, Boston University, Boston, MA, was unable to attend the ceremony but will receive her certificate when delivering the Joseph Leiter National Library of Medicine (NLM)/MLA Lecture on Wednesday, May 20. Mae Jemison received her award when she delivered the John P. McGovern Award Lecture on Sunday. 
MLA grants a scholarship of up to $\$ 5,000$ each year to a student entering an American Library Association (ALA)-accredited library school with at least one-half of the requirements of the program to finish in the year following the granting of the scholarship. The 2015 recipient is Catherine Hana, a student at the University of Western OntarioLondon, Canada. She is interested in directing her career toward consumer health information.

The MLA Scholarship for Minority Students provides $\$ 5,000$ to a minority student entering an ALA-accredited library school with at least one-half of the requirements of the program to finish in the year following the granting of the scholarship. The 2015 recipient is Tyler Moses, a student enrolled in a dual master's program for Library Sciences and Health Studies at Texas Women's UniversityDenton. She plans to be a library volunteer and work as an intern to gain practical library experience. She hopes to assist physicians and medical students with health sciences research.

The Cunningham Memorial International Fellowship was created to assist in the education and training of health sciences librarians from countries outside the United States and Canada. The 2015 recipient is Joseph Olubunmi Olorunsaye, E. Latunde Odeke Medical Library, College of Medicine, University of Ibadan, Ibadan, Nigeria.

Established in 1996, the Hospital Libraries Section/ MLA Professional Development Grant provides librarians working in hospital and similar clinical settings with the support needed for educational or research activities. The 2015 recipient is Amanda Gautreaux, AHIP, Chabert Medical Library, Leonard J. Chabert Medical Center, Houma, LA.

Sponsored by EBSCO Information Services, the 4 EBSCO/MLA Annual Meeting Grants provide up to $\$ 1,000$ each to enable medical librarians new to the profession and working in health sciences libraries to attend MLA annual meetings. This year's winners are: Krystal Bullers, AHIP, emerging technologies librarian and College of Pharmacy liaison, Shimberg Health Sciences Library, University of South FloridaTampa; Suhua Caroline Fan, assistant professor and web services librarian, Health Sciences Library and Biocommunications Center, University of Tennessee Health Science Center-Memphis; Erin Menzies, southern medical program librarian, Okanagan Library, University of British Columbia-Kelowna, Canada; and Michelle P. Rachal, health sciences librarian, Knowledge Center, University of NevadaReno.

The Ysabel Bertolucci MLA Annual Meeting Grant recognizes Ysabel Bertolucci's exemplary career as a member of MLA and her many contributions to its sections, chapters, and board. Endowed in 2014 by the many generous gifts from MLA members, the Bertolucci Grant recognizes a health sciences librarian who is involved in nursing, allied health, consumer health, or international librarianship. The first Bertolucci Grant recipient is Karin Saric, information services librarian, Morris Medical Library, University of Southern California-Los Angeles. Ms. Saric used this opportunity to network with other librarians and gain knowledge she can use in her role as a liaison to the Occupational Therapy and Global Health Divisions at her institution.

As a recipient of MLA's 1986 Frank Bradway Rogers Information Advancement Award for the Georgetown Library Information System and the miniMEDLINE SYSTEM used by over forty libraries, MLA Past President Naomi Broering, AHIP, FMLA, has had a long-time interest in medical informatics and knowledge management. She was the first recipient of the NLM Integrated Advanced Information Management Systems (IAIMS) grant to integrate information. On the occasion of her fortyfive years as a member of MLA, Ms. Broering endowed the Naomi C. Broering Hispanic Heritage Grant. This grant will allow a person of Hispanic or Latino ethnicity to pursue a professional development or research activity in the areas of medical informatics and/or data management to encourage librarians to gain knowledge about these important areas of practice and support MLA's emphasis on evolving roles for the profession.

Established in 2013, the Eugene Garfield Research Fellowship promotes and supports research in the history of information science in the medical or health sciences. The 2015 recipient is Alyson Gamble, librarian, Mote Marine Laboratory, Sarasota, FL. Ms. Gamble's project aims to establish the role of information science in marine research with medical implications by exploring the history of information sciences in marine medical research.

The David A. Kronick Traveling Scholarship was established in 2001, with an endowment from the Bowden-Massey Foundation, and is awarded annually to an MLA member to cover expenses involved in traveling to three or more medical 
libraries in the United States or Canada for the purpose of studying a specific aspect of health information management. This year's recipient is Emily Mazure, AHIP, biomedical research liaison librarian, Duke University Medical Center Library and Archives, Duke University, Durham, NC. Ms. Mazure plans to examine and document the experience and knowledge of libraries and librarians who have long-standing relationships with institutional animal care and use committees.

Endowed in 2014, the Librarians without Borders ${ }^{\circledR}$ Ursula Poland International Scholarship is designed to support projects related to health sciences librarianship in an international context. Ursula $\mathrm{H}$. (Anker) Poland was a distinguished MLA member, and her 1982 Janet Doe Lecture is one of MLA's most important statements about international interests and accomplishments. Poland used the Doe Lecture forum, other publications and activities, and her own career as a model to encourage MLA members to enrich their careers and approach to the practice of health sciences librarianship through international connections and experiences. The first recipient of the Poland Scholarship is Sue Espe, AHIP, Southwest College of Naturopathic Medicine, Tempe, AZ. Ms. Espe will use this scholarship to purchase print copies of essential medical books to establish a mobile core collection for Naturopaths without Borders, which serves the impoverished communities in Rocky Point, Mexico.

The Donald A. B. Lindberg Research Fellowship, named in honor of Donald A. B. Lindberg, retired director, NLM, funds research aimed at expanding the research knowledgebase, linking the information services provided by librarians to improved health care and advances in biomedical research. This year's fellowship is awarded to Lorie Kloda, AHIP, assessment librarian, McGill University Library, Montreal, QC, Canada.

The MLA Continuing Education Award provides monetary awards to MLA members to develop knowledge of the theoretical, administrative, or technical aspects of librarianship. Leah C. Osterhaus Trzasko, Learning Resource Center (LRC), Mayo Clinic, Rochester, MN, is one of this year's recipients. Ms. Trzasko is using her grant to take an online continuing education course in evidence-based medicine for the medical librarian to further her knowledge and improve her ability to teach in her new role at the LRC. Jennifer S. Walker, AHIP, University of North Carolina-Chapel Hill, is the second recipient. Ms. Walker is using her grant to take a course designed as an introduction for medical librarians to the practice of evidence-based medicine. She hopes to expand services in the oncology department, and this course will better prepare her for her role as a clinical informationist.

Named in honor of Virginia L. and William K. Beatty, the Virginia L. and William K. Beatty MLA Volunteer Service Award recognizes their significant contributions to MLA and the profession as longtime volunteers to the association. The 2015 recipient is Dolores Judkins, AHIP, Kaiser Permanente Center for Health Research Library, Portland, OR. Ms. Judkins has a distinguished career of service to MLA, its chapters, and sections. She has been involved with small hospital libraries, large academic settings, nurses, public health employees, new librarians, and experienced librarians and is known by her peers to give both her time and energy willingly and without hesitation.

The Estelle Brodman Award for the Academic Medical Librarian of the Year was established with a gift from Irwin H. Pizer and is given to a member who has made outstanding contributions to academic medical librarianship as demonstrated by excellence in performance, publications, research, service, or a combination thereof. This year's recipient is Melissa Rethlefsen, AHIP, Spencer S. Eccles Health Sciences Library, University of UtahSalt Lake City. Known as a highly accomplished academic health sciences librarian, Ms. Rethlefsen is well respected by her peers. Her drive and inquisitive nature have led her to be a true professional in the field, but it is her character and willingness to empower others that truly set her apart. Ms. Rethlefsen is a dynamic and thoughtful leader who continues to elevate the practice of health sciences librarianship.

The Lois Ann Colaianni Award for Excellence and Achievement in Hospital Librarianship is given to an association member who has made significant contributions to the profession through overall distinction or leadership in hospital library administration or service, production of a definitive publication related to hospital librarianship, teaching, research, advocacy, or development or application of innovative technology to hospital librarianship. This year's recipient is Geneva Bush Staggs, AHIP, Biomedical Library, University of South Alabama-Mobile, for her service in the profession, mentoring new librarians, leading research projects, and advocating for hospital librarians. Ms. Staggs was a key member of the USA 
Heart Team at her medical center and helped to establish best practices and saw that the most up-todate information was used by each department. She also helped to develop a robust patient information package that resulted in positive patient feedback and has earned high praise from her colleagues, administrators, and trainees.

The Louise Darling Medal for Distinguished Achievement in Collection Development in the Health Sciences recognizes accomplishment in collection development for health sciences. The 2015 recipient is the HINARI Access to Research in Health Programme, World Health Organization (WHO), Geneva, Switzerland. HINARI is a free and low-cost research access program for developing country researchers, doctors, librarians, and policy makers. It was launched in 2002, when WHO collaborated with 6 publishers in making 1,500 journals freely available. Today, HINARI has grown to include 170 publisher partners and content from 400 publishers, offering more than 51,000 information resources. Nathan Rupp, Cushing/Whitney Medical Library, Yale University, New Haven, CT, accepted the award on behalf of the HINARI Programme.

The recipient of the Carla J. Funk Governmental Relations Award is Karen M. Albert, Paul J. Gutman Library, Philadelphia University, Philadelphia, PA. The Government Relations Award, endowed by Kent Smith, FMLA, recognizes a medical librarian who has demonstrated outstanding leadership in the area of governmental relations at the federal, state, or local level and who has furthered the goal of providing quality information for improved health. Ms. Albert's interest and participation in supporting scholarly communications initiatives and legislation at the federal, state, and local levels is clear. She has served MLA in many leadership roles including as chair of MLA's Ad Hoc Committee for Advancing Scholarly Communications. She is considered an accomplished librarian and a true leader by her peers. The impact of her leadership and vision for the changing landscape of scholarly communications and its impact on the library and library services resulted in the establishment of the standing Scholarly Communications Committee in 2013.

Recognizing a work published in the preceding year that has been judged most effective in furthering medical librarianship, the Ida and George Eliot Prize is awarded to Laure Perrier, Li Ka Shing Knowledge Institute, St. Michael's Hospital, Toronto, ON, Canada; Ann Farrell, Mayo Clinic Libraries, Mayo Clinic, Rochester, MN; Ana Patricia Ayala,
Gerstein Science Library, University of Toronto, Toronto, ON, Canada; David Lightfoot, Health Sciences Library, St. Michael's Hospital, Toronto, ON, Canada; Tim Kenny, George J. Farha Medical Library, School of Medicine, University of Kansas-Wichita; Ellen M. Aaronson, AHIP, Medical Library, West Hills Hospital \& Medical Center, West Hills, CA; Nancy J. Allee, AHIP, Taubman Health Sciences Library, University of Michigan-Ann Arbor; Tara Brigham, Winn Dixie Foundation Medical Library, Mayo Clinic, Jacksonville, FL; Elizabeth Connor, AHIP, Daniel Library, The Citadel, Military College of South Carolina-Charleston; Teodora Constantinescu, Dr. Henry Kravitz Psychiatry Library, Institute of Community and Family Psychiatry, Jewish General Hospital, Montreal, QC, Canada; Joanne M. Muellenbach, AHIP, Library, Commonwealth Medical College, Scranton, PA; Helen-Ann Brown Epstein, AHIP, Sidney Silverman Library, Bergen Community College, Paramus, NJ; and Ardis Weiss, Pomona Valley Hospital Medical Center, Pomona, CA. Their article "Effects of Librarian-Provided Services in Healthcare Settings: A Systematic Review," squarely relates library service as integral to patient care, including provider training, which many regard as future patient care. The paper is relevant to today's health care climate that focuses on patient satisfaction backed by a massive new legal and regulatory framework, including new requirements and concepts such as meaningful use, that involve information and ultimately skilled use of the literature. Ms. Epstein accepted the award on the group's behalf.

The Murray Gottlieb Prize was established in 1956 by a gift from Ralph and Jo Grimes of the Old Hickory Bookshop in Brinklow, MD, to recognize and stimulate health sciences librarians' interest in the history of medicine. The 2015 prize is awarded to Elena Safia Azadbakht, Joseph Anderson Cook Memorial Library, University of Southern Mississippi-Hattiesburg, for her paper, titled "The Legacy of Color Vision Testing in the Railway Industry." Her paper took what could have been a narrow topic and placed it in a larger and relevant context, that of a piece of the history of occupational health. Ms. Azadbakht went beyond traditional research methodology and databases by analyzing the sources of that era, heavily referencing a journal and manual as evidence of the day's practices and opinions.

The Majors/MLA Chapter Project of the Year Award is sponsored by the J. A. Majors Company and recognizes excellence, innovation, and 
contributions to the profession of health sciences librarianship, shown through special projects beyond the normal operational programming of a chapter. The Medical Library Group of Southern California and Arizona (MLGSCA) was selected to receive the 2015 award for its "Chapter Outreach and Promotion to Non-Medical Librarians in Arizona," a special project to promote the organization to share timely health information resources and information.

MLGSCA exhibited at the Arizona Library Association Conference, created an Arizona-specific Affordable Health Care handout, and used an iPad to demonstrate resources and engage with attendees. This project improved the visibility of medical librarians and their willingness to assist public, school, and community college librarians with health-related questions. Sondhaya (Sunny) Sritongsook accepted the award on the chapter's behalf.

The Medical Informatics Section (MIS) established the MIS/MLA Career Development Grant in 1997 and awards one individual a grant to support a career development activity that will contribute to the advancement of the field of medical informatics. This year's grant recipient is Jennifer Dinalo, reference and instructional librarian, Martin Luther King, Jr. Library, San Jose State University, San Jose, CA. This grant will enable Ms. Dinalo to participate in the NLM course, "A Librarian's Guide to National Center for Biotechnology Information (NCBI)," which will allow her to further develop her professional knowledge and skills.

The MLA Research, Development, and Demonstration Project Grant promotes excellence in health sciences librarianship and information science. This year's grant is awarded to Misa Mi, AHIP, Kresge Library, Oakland University William Beaumont School of Medicine, Rochester, MI, for her research project, titled "Health Professions Students' Lifelong Learning Orientation: Associations with Self-Assessed Competency in Information Skills." Ms. Mi's project is an endeavor to glean any information that would help health professions educators develop and integrate strategies and activities into their curricula to meet accreditation standards and to affect students' lifelong learning attitude and information competence.

The Section Project of the Year Award is awarded to an MLA section that demonstrates creativity, ingenuity, cooperation, and leadership within the framework of the mandate of the section. The 2015 winner is the Educational Media and Technologies
Section for its webinar, "Delving into Distance Support: Instructional Design, Library Role, and Social Media." The webinar was provided at no cost to the library community and reached seventy participants. Amy Blevins accepted the award on behalf of the section.

The Rittenhouse Award, sponsored by Rittenhouse Book Distributors, is presented for the best unpublished paper on medical librarianship written by a student or recent graduate from an ALA-accredited school of library sciences or by an intern in health sciences librarianship or medical informatics. The 2015 recipient is Nicole Dalmar, University of Western Ontario-London, Canada, for her paper, "Social Media: Evolving Assessments of Online Health Information Reliability." Ms. Dalmar researched beyond library sciences and recognized the gray literature as well as traditionally published literature on this important topic for libraries given the popularity and changing environment of social media.

The T. Mark Hodges International Service Award was established in 2007 to honor outstanding individual achievement in promoting, enabling, and/ or delivering improvements in the quality of health information internationally through developing health information professions, improving libraries, or increasing use of health information services. The 2015 award recipient is Kimberly Parker, programme manager of HINARI at the World Health Organization, Geneva, Switzerland. Ms. Parker's work has enabled thousands of health professionals, researchers, and academicians in over 105 developing countries to access evidence-based, upto-date, peer-reviewed, and high-quality health and biomedical literature via the Research4Life publicprivate partnerships.

The individuals chosen to deliver the Janet Doe Lecture are selected for their unique perspectives on the history or philosophy of medical librarianship. This year's presenter, Barbara A. Epstein, AHIP, has been the director of the Health Sciences Library System at the University of Pittsburgh since 2004, overseeing an academic library and three hospital libraries. Within the medical librarian profession, Ms. Epstein is a thought and practice leader in the areas of library management, research and scholarship, teaching, and library organizations. She serves as the director of the Middle Atlantic Region (MAR) of the National Network of Libraries of Medicine (NN/ LM). In addition to serving as a member of Board of Directors of the Association of Academic Health 
Sciences Libraries (AAHSL), she has served as chair of several MLA committees, a regional MLA chapter, and an MLA section. Ms. Epstein has authored numerous impactful articles, book chapters, and presentations and her scholarship has taken the profession to new places. Ms. Epstein delivered this year's lecture on Monday, May 18.

The 2014/15 Board of Directors has named five association members as Fellows of the Medical Library Association. Fellows are chosen for their outstanding contributions to health sciences librarianship and to the advancement of the purposes of MLA.

With a career in hospital librarianship, health sciences library education, and health sciences library research spanning over forty years, Cheryl R. Dee, FMLA, has significantly impacted the lives of numerous health sciences librarians and increased the evidence-base at the foundation of health sciences librarianship through her diverse and robust record of scholarship, research, teaching, and service. Dr. Dee has demonstrated notable leadership in MLA as chair of the Hospital Libraries Section, chair of the Medical Library Education Section, chair of five MLA award juries, member of MLA's first Research Task Force, and member of the MLA Mentoring Task Force. She has received numerous awards including the Thompson Reuters/MLA Doctoral Fellowship, the Lois Ann Colaianni Award for Excellence and Achievement in Hospital Librarianship, the Ida and George Eliot Prize for her article on using scientific evidence to improve hospital library services, and the Hospital Libraries Section Professional Recognition Award for Research.

Currently serving as associate director for user experience at the University of Washington Health Sciences Library-Seattle, Terry Ann Jankowski, AHIP, FMLA, has nearly forty years of experience in academic health sciences librarianship. Ms.

Jankowski is a notable MLA leader at the national level as evidenced by her serving as editor of the MLA News Expert Searching column for ten years, chairing the MLA Continuing Education Committee twice in ten years, serving on the Editorial Board of the Bulletin of the Medical Library Association, chairing the National Program Committee, chairing the MLA Pharmacy and Drug Information Section and the MLA Public Services Section, chairing the Lucretia W. McClure Excellence in Education Award Jury, and convening the Online Searching Special Interest Group. Ms. Jankowski has given her time and energy to service as a member of the Task Force on the MLA Academy for Teaching Excellence, Programming Section Council/Chapter Council Joint Task Force, MLA Nominating Committee, and the Task Force on MLA's Educational Policy Statement. She has also been an active leader in the Pacific Northwest Chapter.

With energy, commitment, and passion for the profession, Beverly Murphy, AHIP, FMLA, assistant director for communications and web content management, Duke University Medical Center Library and Archives, Duke University, Durham, $\mathrm{NC}$, has embodied exceptional leadership and defined both dedication and joy in continuous service to MLA and the Mid-Atlantic Chapter throughout her career. Ms. Murphy serves as a mentor for the Academy of Health Information Professionals and as a liaison to the MLANET Task Force. She has also served on the Continuing Education Committee, Publications Committee, Credentialing Committee, and the 2004 National Program Committee Local Assistance Committee. She brought her editing expertise to the MLA News for six years and has recently been appointed to the Journal of the Medical Library Association Editorial Board. After serving on the Nominating Committee and working on the MLA Diversity Symposium Planning Group, she became chair of the Professional Recruitment and Retention Committee. All this work culminated in her election to the MLA Board of Directors. Ms. Murphy's many years of leadership and service at the chapter level were recognized by her colleagues when she was presented with the Mid-Atlantic Chapter's highest awards, the Marguerite Abel Service Recognition Award and the Mid-Atlantic Chapter Librarian of the Year Award.

Tovah Reis, FMLA, worked for twelve years in academic libraries in Israel and the United States before taking on the position of library director in 1978 at the Chaim Sheba Medical Center, Israel's largest public medical center in Tel-Hashomer, Israel, where she served for ten years and was awarded the Sheba Prize for her outstanding contributions. Ms. Reis served as the medical school librarian for Brown University in Providence, RI, for almost twenty years, where she developed exceptionally strong partnerships with medical faculty and students, and proactively and creatively led and guided transformational change, including a challenging, yet ultimately effective, transformation from print to electronic. Not long after her retirement from Brown in 2010, she was asked to serve as interim director of the James P. Adams Library at Rhode Island College- 
Providence, providing leadership in the transformation of the library's physical space. Ms. Reis's leadership in MLA is exemplified by her service on the MLA Board of Directors and as Section Council chair.

At the time of her retirement in June 2014, Julia Shaw-Kokot, AHIP, FMLA, had served twenty-three years of her thirty-year health sciences librarianship career at the Health Sciences Library, University of North Carolina-Chapel Hill, most recently as assistant department head for user services and education services coordinator and as adjunct assistant professor in the School of Nursing. Ms. Shaw-Kokot has a long history of strong and consistent leadership in MLA and in the Mid-Atlantic Chapter. She served as chair of Chapter Council, representing Chapter Council on the MLA Board of Directors. She has also served as chair of the MLA Awards Committee, chair of the Rittenhouse Award Jury, and as Chapter Council representative to the MLA Continuing Education Committee. Ms. Shaw-Kokot's service has been particularly noteworthy in the Mid-Atlantic Chapter (MAC), for which she served as chair as well as treasurer. In recognition of her dedicated service to the chapter and excellence in medical librarianship, MAC honored her with the Marguerite Abel Service Recognition Award and the MAC Librarian of the Year Award in 2007. Ms. Shaw-Kokot was a very active member of the MLA Emerging Leaders Task Force, which implemented the MLA Rising Stars program, and contributed significantly to the program's early success.

The highest honor that the Medical Library Association confers on any individual is the Marcia C. Noyes Award. President Walton asked Joanne Gard Marshall, AHIP, FMLA, recipient of the 2014 Noyes Award, to introduce this year's recipient, J. Michael Homan, AHIP, FMLA, retired, Mayo Clinic Libraries, Mayo Clinic, Rochester, MN.

Joanne Gard Marshall, AHIP, FMLA: At Michael's special request, I am going to make this very brief, and it was a struggle to do that because he has such a long, wonderful career. It's a great pleasure to introduce J. Michael Homan, AHIP, FMLA, this year's winner of the Marcia C. Noyes Award, our association's highest professional distinction. The award recognizes a career that has resulted in lasting, outstanding contributions to medical librarianship, and Michael is a very worthy recipient. Michael was born in Portland, Oregon, but grew up in the wonderful Wallowa mountains of northeast Oregon. His dad was a pharmacist and instilled the first service attitude in him when he worked as a soda jerk at the drug store soda fountain and washed the drug store windows in the summers during junior and senior high school. Michael also had a great aunt who opened the first Carnegie-funded library in his hometown. So both medicine and libraries ran in the family.

Michael began his career as a biomedical library intern at the University of California-Los Angeles (UCLA) Biomedical Library in Los Angeles in 1971. Then he went on to a distinguished library career at the Pacific Southwest Regional Medical Library system, the University of California-Irvine, Upjohn Pharmaceutical Company, now Pfizer, before becoming director of the Mayo Clinic Library and Archives in Rochester, Minnesota, in 1994. As my friend Carol G. Jenkins, AHIP, FMLA, said, "Michael has done it all." Fortunately for us, Michael also became a very active member of MLA and AAHSL. He has been a prolific contributor to the literature of our field and a frequent speaker at our meetings. The esteem with which Michael is held by his colleagues is shown by his selection as editor of our journal, the Doe Lecturer, and president.

In addition to all his professional achievements, Michael has been a friend and supporter of so many of us over the years. His sincerity, modesty, and affable nature make being in his company a joy and a pleasure. Michael, congratulations from all of us at MLA and from all of the communities you have served over the years as you receive this great distinction.

President Walton presented Homan with an engraved silver bowl from MLA and flowers from the foundation of MedChi, the Maryland State Medical Society where Marcia C. Noyes worked for fifty years. Mr. Homan made the following remarks.

J. Michael Homan, AHIP, FMLA: Thank you very much. I feel I need to make a disclaimer first. Those of you who attended the Doe Lecture, the wonderful Doe Lecture, by Barbara Epstein, AHIP, learned that one of my predecessors received a six-week, allexpenses-paid vacation to Europe with his wife on the occasion of his retirement. That did not happen to me. If I had read the transcript, maybe I would have requested that, but I didn't.

Thank you so much, Joanne, for your gracious and generous introduction. You've always been one of my professional heroes, so hearing your introduction was that much more meaningful to me. I also want to sincerely thank the nomination team, without whom 
there would no nomination form or supporting documentation for the jury and the Board of Directors to act on. Those of you who are working on juries know that there has to be a nomination form and supporting documentation, so your belief that I might be worthy of it, this highest honor of MLA, is award in and of itself. So a heartfelt thanks to all of you.

As Joanne mentioned, I began my career at the UCLA Biomedical Library in 1971. The primary information retrieval system in medicine was the National Library of Medicine's MEDLARS system, and part of my internship year, and later my first job, was at the UCLA MEDLARS center. Some of you in the audience, of course, were probably not born in 1971 and definitely don't know what MEDLARS was. I can still bring up vivid memories of doing MEDLARS searches in my little cubicle on the twelfth stack level of the UCLA Biomedical Library, filling out the data form with Medical Subject Headings (MeSH) terms and the formulation where an asterisk was a Boolean "AND" and a plus sign was the Boolean "OR." But things were rapidly changing in 1971, and during the years I spent at UCLA as an intern and later as an employee of UCLA MEDLARS center, AIMTWX was developed for NLM by the Systems Development Corporation in Santa Monica, which as you know morphed into ELHILL MEDLINE, well, those of you who are old enough to remember ELHILL MEDLINE will remember that, and of course later into the NCBI and PubMed system. These were heady and exciting times for NLM, MEDLARS centers, Regional Medical Libraries, and medical librarians in general, and my early MEDLARS searching and MEDLINE teaching experience formed the basis of my lifelong interest in information retrieval, online training, and access to the biomedical literature.

Perhaps because I began my career in a Regional Medical Library funded by NLM, I also gained an early appreciation for the exceptional leadership, planning, and foresight of our national library, the National Library of Medicine. But something else occurred in those early years of my career that was to permeate my professional activities really to the present day. I slowly developed a personal commitment to volunteerism, participating in activities where I could promote and encourage something greater and more lasting than my own career or even the institution where I was currently working at. The initial encouragement to join MLA came most likely from peer pressure, from my committed colleagues at UCLA, and our redoubtable leader at the time, Louise Darling. I can still hear Louise saying, "Michael, you need to be a member of MLA." And in those years, in the 1970s, you really paid attention to what your boss said. So I became a member of MLA. But over time and through experience working on committees locally and nationally, the initial peer pressure to be involved in MLA and local chapters grew into an ongoing avocation in my professional life and a way of supporting and developing and nurturing institutions I find highly worthy of my time and energy, including the Medical Library Association, its various units, chapters, sections, and so forth; AAHSL, the Association of Academic Health Sciences Libraries; the Association of American Medical Colleges (AAMC); and of course, NLM. Commitment to these organizations through committees and task forces and leadership positions sometimes felt like a second job, and I'm sure the members of the Board of Directors and past presidents know exactly what I'm talking about, but always a fun and rewarding second job, primarily because I was working with other like-minded medical librarians who had a passion for their profession.

I've had such fun in the past forty years working with the highly talented and committed individuals at institutions I have served, the medical library community, and our colleagues in the publishing industry, medical societies, and others. This award is a wonderful capstone to a career I have loved, and I will treasure it always. My greatest reward, however, has been the work we have all accomplished together as an association of professionals with the unique knowledgebase and commitment to the improved health of the nation. What we do as medical librarians remains terrifically important to society, and being a part of this great enterprise has been a wonderful career for me. Thank you most sincerely for this great honor.

President Walton concluded the awards ceremony and luncheon with the following remarks: "Each year, the awards ceremony and luncheon reminds us of the outstanding accomplishments our peers have made to the profession of health sciences librarianship. It simultaneously provides the encouragement to continue striving to new levels of achievements. In recognizing these individuals, we applaud the 'best and brightest' in the field." 


\section{BUSINESS MEETING 1}

Business Meeting 1 was held on Sunday, May 17, from 3:00 p.m.-4:25 p.m. President Linda Walton, AHIP, welcomed everyone to MLA Business Meeting 1 and introduced MLA's new Executive Director Kevin Baliozian, who presented the members of 2014/15 MLA Board of Directors: President Linda Walton, AHIP; President-Elect Michelle Kraft, AHIP; Immediate Past President Dixie Jones, AHIP; Treasurer Chris Shaffer, AHIP; Secretary Sandra G. Franklin, AHIP; Chapter Council Chair Angela Dixon; Section Council Chair Jodi Philbrick; and Directors Kristine Alpi, AHIP; Melissa de Santis, AHIP; Julia Esparza, AHIP; Heidi Heilemann, AHIP; and Theresa L. Knott, AHIP. Mr. Baliozian then introduced appointed officers, editors, and coordinators: Parliamentarian Patricia Thibodeau, AHIP, FMLA; Sergeant-at-Arms Linne' Girouard; MLA News Editor Cheryl Rowan; Journal of the Medical Library Association Editor Diane Cooper, AHIP; and MEDLIB-L Coordinator Judith Mills.

President Walton then remarked on the deaths of a number of MLA members during the past year. A short video was shown to honor the memories of: Mary Jo Dwyer Miller, April 9, 2015; Gertrude Lamb, March 15, 2015; Gay Gipson Middleton, October, 18, 2014; Kimberly Arnold Pullen, September 25, 2014; Graciela (Greysi) Reyna, July 20, 2014; Steven Fiske Ruppenthal, June 20, 2014; and Pauline M.

Vaillancourt, June 11, 2014.

Mr. Baliozian returned to the podium to recognize the vital role the 13 MLA chapters play in bringing the benefits and services of the association to members at the regional, state, and local levels. He also recognized the 22 sections and special interest groups of MLA that provide significant networking and professional development opportunities for MLA members in their areas of specialization, allowing specific needs and issues to be addressed. He also acknowledged committees, task forces, and representatives to allied organizations for their crucial role in the success of MLA's programs and services. He then remarked that 270 new members have joined MLA since the 2014 annual meeting.

President Walton then called to order Business Meeting I of the 2015 MLA Annual Meeting and asked if a quorum of 250 voting members required for transaction of business was present. Sergeant-atArms Thibodeau confirmed the quorum and President Walton called on Secretary Franklin to move adoption of the Rules of Assembly. Ms.
Franklin explained that the Rules of Assembly include information on addressing the chair, presenting motions, debating, and voting. At the direction of the Board of Directors, she moved that the Rules of Assembly as they appear on MLANET be adopted. Voting paddles were raised, and there being a majority in the affirmative, the rules were adopted. Ms. Franklin then announced that each meeting registrant had a printed copy of the Official Program and that the agendas for the 2015 Business Meetings were on pages 28 and 39. She moved that the agendas be adopted. The vote was affirmative, and the agendas were adopted.

President Walton announced the ballots for MLA's election of 2015/16 Officers, Board of Directors, and Nominating Committee were sent electronically or by postal service to all 3,145 eligible voting members of the association. One thousand two hundred and twenty-five valid ballots were returned, with a participation rate of $38.95 \%$. The election results were certified by Survey \& Ballot Systems of Eden Prairie, Minnesota, MLA's election contractor, on December 15, 2014. Election results were announced in the December 22, 2014 issue of MLA-FOCUS and in the February 2015 issue of the MLA News. Complete election results, including vote totals, are published in the 2014/15 Annual Report, which is available on MLANET.

Election results: President-Elect: Teresa L. Knott, AHIP; MLA Board of Directors (three-year term): Lisa K. Traditi, AHIP; Melissa Retlefson, AHIP; Chris Shaffer, AHIP; Nominating Committee: Marie T. Ascher; Donna R. Berryman; Michael S. Fitts; Stephanie Fulton, AHIP; Emily J. Hurst, AHIP; Latrina Keith; Julie K. Kwan; Terri Ottoson, AHIP; and Brandi D. Tuttle, AHIP. Dixie A. Jones, AHIP, MLA's 2014/15 immediate past president will chair the 2015/16 Nominating Committee.

President Walton then called on Treasurer Chris Shaffer to present the treasurer's report.

Chris Shaffer, AHIP: So you may recall that last year my first slide was a big pile of money and the statement that we're rich! This year, Ray Naegele had a conversation with me before I prepared my slides and asked for a more restrained approach, which is actually appropriate given our current situation.

When we think about the future of the profession and our professional lives, we should definitely think big, like this year's MLA theme, "Librarians without Limits." We should allow our planning to extend beyond our traditional boundaries and stretch our 
imaginations. However, in my role as treasurer of MLA, I must work with our financial staff to think in terms of keeping within limits. I'm sure all of you who manage budgets for your organizations or families know that an essential ongoing function is keeping costs in line with budget targets and identifying new cost controls and ways to save money.

So for 2014, MLA's operating fund finished the year with a total revenue of $\$ 2,799,186$, which was below budget by $\$ 205,589$ or $7 \%$. Most of the shortfall was offset by better than budgeted expenses - in other words, cost-cutting - for a total of $\$ 2,843,373$, which was under budget by $\$ 159,497$. The resulting net revenue was a deficit of $\$ 44,187$. So we ended the year slightly below where we did last year, when we had actual profits of $\$ 62,494$.

This deficit is due to several factors: decline in revenues due to softness in advertising, display ads, and so forth; subscriptions; meeting fees; and the non-renewal of the contract, the American Library and Information Science Educators Service Agreement, under which we were running their association business.

Also, about $50 \%$ of the deficit is a one-time accounting adjustment recommended by our auditors in the way that we bill our taxes and audit fees and that will not recur. As an offset for these declining revenues, headquarters staff initiated expense cuts, including reductions in staffing, reductions in outside services, and delayed and deferred purchases.

Helping the bottom line, on the other hand, was good attendance at a popular new series of webinars. And I'm sure you'll all be happy to hear there was a big jump in classified job advertising, reflecting increased strength in the medical library job market.

In October 2014, the Board of Directors approved the 2015 business plan and budget. The budget projects revenues of $\$ 2,800,000$ and expenses of about the same, for a net of $\$ 5,600$. The objective of the budget is to project revenues and control expenses in order to provide the resources we need for our association business.

Attendance here at Austin is on track and actually exceeded projections, and I'm happy to announce that online registration for our e-conference exceeded expectations significantly as well, another reflection in the medical library community and job markets.
MLA's budget is based on the association's financial plan, which classifies expectations according to cost centers. As I've mentioned in several previous reports, dues only cover $21 \%$ of our total expenses, well below the average for similar associations of $38 \%$. The remaining $79 \%$ of expenses is covered by revenues, by our cost centers, and entrepreneurial areas.

Two thousand fifteen is a transition year for MLA, with a new executive director. Exciting initiatives are under way that will transform and improve your benefits as a member of MLA. And along with this comes a renewed focus on data, and metrics, and evaluations of all of our programs and services that you'll be hearing about from Kevin Baliozian and other members of the board as the meeting goes and going into the future.

Some of these will have budget implications, but we are happy to have better reporting and dashboards provided by the MLA staff, and this is just an example of some of the reports that have been presented to the board and that will allow the board to have a more in-depth role in planning for the association and reacting to adjustments in finances and activities as we go forward. We're really happy with these new dashboards, which are still being developed and look forward to being able to share some of those with our members, for those of you who are interested in digging into the details of the association.

Along with this we are looking to fund our member benefits, to use our finances wisely, to maintain the current excellent benefits and services that we have, to build our continued advocacy for the profession, and you'll be hearing lots about new tools to build our communities.

Many of you are using the new MLA meeting app, the icon there on the right-hand side of the screen, and many of you, especially those involved in sections, have heard about the new initiative to implement Socious, a new online platform for MLA to build better tools for our communities and to give us new options for allowing members to interact with each other in a consistent and coherent way and to build groups together among the association.

For more information about MLA's finances, the 2015 Business Plan was outlined in the recent April issue of the MLA News. In June, MLA published on MLANET a detailed, audited, year-end financial analysis containing balance sheets, fund status reports, and many other details, including our 
investments. Members may also obtain year-end financial analysis from MLA headquarters after June 1 , 2015. For more information about the budget or for a copy of the business plan, feel free to contact me or Ray Naegele.

Thank you very much.

Next, President Walton called on Executive Director Kevin Baliozian to give the executive director's report.

Kevin Baliozian: Thank you, Linda. Yes, I'm the new guy. You probably know this by now. Before I tell you a little bit about where I come from and some of the things we've achieved in the four months and two days now that I've been here, I just wanted to express my sincere thanks to this amazing welcome I've had from day one-from Carla J. Funk, $\mathrm{CAE}$, where we basically on my first two days drank wine, which was wonderful. I thought that's what we did every day but apparently only on Fridays. Just kidding. We don't even do that on Fridays.

The staff has been absolutely amazing in their welcoming, in their amazing knowledge, in their ability to embrace change in a new person after twenty-two years and ten months working with Carla. Working with the board and with the committees that I have thus far been close to has been very rewarding and interesting.

And my first impression-someone asked me in the last few days what was one thing-well, the one thing I sense is just incredible engagement from all of you. Obviously, a lot of expertise and competence as well. And that is just precious and should not be taken for granted. You all lead very busy lives. You have jobs, apparently, outside of MLA, which is great. And I really do appreciate all of you coming forward and giving me your welcoming, and advice, and ideas. It's all great.

So I won't be spending much time talking about my achievements for MLA in the last year because, really, the list is very short, but maybe giving you a little angle on where I come from, some of the approaches I have. Then given enough time for Q\&A, which I understand is a new feature, perhaps, of this meeting - and we've had a number of questions and answers in some of the sessions leading to this. So let's have some fun.

So this guy here, good-looking Navy man, is my dad. And it's a picture of him when he was in the US Navy back in 1943. He was a Navy photographer in the Pacific and decided right around then, as he was going off and on submarines and airplanes taking recon pictures, that he wanted to be a fashion photographer.

So the war finished, he did the GI Bill, and then he moved - where else? - from Larchmont, New York, to Paris. Met my mother. That's another long story, but this is where my sisters and I were born. We were born in Paris, with my father having built a notso-successful photo business until my mom really started taking care of it; where this business then became very, very successful, and I was raised in a family business environment-breakfast, lunch, dinner, 24 hours, 365 days a year. I had the opportunity to go to the United States for college and then came back and worked in the family business.

So this is a picture of me working in research and development. I actually did electronics, and design, and programming. I traveled the world doing sales, so this is an example of a brochure in Japan that I was involved with. Worked in Chicago for a number of years. Sold that business back in the early '90s. And then my wife and I moved to France for a year and came back fifteen years later with three kids and two cats. Then I got into the association management business, managing health care organizations, and then after a number of different twists and turns got selected by the board to lead MLA as the executive director. So lots of interesting connections, which I'll get to in a minute.

Disruptive technologies in photography. This is something that certainly spoke to me and hopefully will speak to you. And here are two examples of disruption. One was Kodak, the inventor of the digital back; another one, Adobe, with Photoshop. All of you are familiar with Photoshop, and this is early '80s. Developing a product that based on cheaper PCs, and obviously the Internet exploded the two in combination-digital photography.

This is a headline I just captured probably a week ago in Bloomberg talking about the fact that the $1 \mathrm{R}$ photo business is essentially dead, and there are just 190 from a total of 3,066 a number of years ago. That is a $94 \%$ drop in that specific business. Talk about disruption-having, in this particular case, a negative effect. Fairly impressive.

This is an interesting picture, the Leica. Particularly, it says, "Lifetime investment in perfect photography." Who buys a smartphone today with the idea that this will be a lifetime investment as a camera? Probably not many people. And you probably remember all these campaigns, and 
Nikons, and Canons. You've probably seen those about the quality in photography and so forth. And who is doing these campaigns today? Companies like Apple and Sony, who weren't involved in the business.

So disruption certainly hit our family business. Within a number of years, half our customersphotographers - went out of business. The others didn't really have any money to buy equipment. They had to reinvent their jobs from being photographers to being more than photographers to managing campaigns, to being involved in marketing, to being involved, eventually, in social media and different things. Really an upheaval that was fairly significant.

I had to manage the bankruptcy of our business back in 2005, which was at that point a sixty-year-old company that we basically had to sell off for nothing to a company that purchased it and who itself went bankrupt a few years later. And in fact, every company, really, in that business has become a shadow of itself.

The irony is Kodak, who created the digital back and in that process killed itself. And I'm not suggesting any parallels that's right now in terms of open access and the ability for free information and so forth. But sometimes things have unintended consequences and are a good idea but do significantly affect sometimes the business model and the function of those who actually are the inventors or the protagonists of those ideas.

So that's the connection I see in terms of my background, coming into the health information field and MLA, some parallels in terms of disruption and what effects those things can have, certainly in roles and in positives and negatives.

Because you can think in photography, it's amazing what's happened. People are enabled. Millions and billions of pictures being taken. Think of Twitter and everything and photos. So easy. So the consumer really has benefited a great deal from this revolution. And some companies have just built entire business models-Flickr and so forth-around photography, and others have disappeared. The list is long of those who have disappeared.

So disruption has positive effects for some and negative for others. So PubMed, Google, Google Scholar, obviously, the Internet. You know more than I do by a longshot about how disruptive that is. And "disruptive" is not a negative term; it's just that it fundamentally changes things, and certainly access to information has been greatly improved.

Now, what happened in photography is that people started accepting lower quality information, lower quality photos, because it was free; it was really, really cheap. The same thing is happening with phones, really. Remember those ads? You can hear a pin drop? The quality of conversation stinks on most cell phones. But it's free-or you think it's free. And so people's perceptions of what they want in terms of quality has gone down.

And one of the frustrations that we have in our area, of course, is that the quality of information, yeah, it's free, but you don't have the quality you need. The big difference in health care is, it's life or death, it's a quality of outcomes difference. With photography, no one's going to die because of a bad picture. So the stakes are obviously much higher in our field and that certainly makes a difference.

Disruption can be good as well, and certainly we heard from Lucretia W. McClure, AHIP, FMLA, this morning when she mentioned to our new members about the Medical Library Assistance Act of 1965 that had a disruptive, very positive effect in hospital libraries by really spearheading a tremendous amount of investment, and construction, and so forth. And right now the pendulum has kind of swung a little the other way: a lot of frustration with the Joint Commission's removal of the word "librarian" in the requirements, libraries closing, or these budgets definitely in many ways being reduced. These are the positive and negative effects of disruption, technology, regulation, and so forth.

So a lot of, in fact, similarities. I wouldn't say "comfort zone," but I certainly feel comfortable coming into an environment where roles are being refined and where significant things need to happen.

So what do I do all day? I have a swivel chair. In fact, it's a standard issue in the entire office, so that's a great thing. I'll stop in a couple seconds. This is probably getting really annoying. So Linda mentioned, you hired an executive director, and the role of the executive director - there are two lists, but the steward and the concept of being a steward is important. Steward is taking care of something you don't own, so you own MLA. I'm a steward, in terms of your staff officer. And there's the word "care," but there's also the understanding that you are the owners of this association, and it is yours and that I'm helping you achieve your objectives. 
Lead, inspire, manage, communicate - that's really the leadership aspect. Execution, operational excellence is, of course, something that we need to do, and we need to achieve the strategic objectives. That's in part of my responsibilities. Of course, a lot of people are involved, many of you sitting in the room. Managing programs, engaging members, and of course, managing and developing staff and volunteers. That is also considered to be part of what I can contribute to. It is an important part of what you should be expecting from your executive director.

There are a couple books. And I'm getting my citations straight; otherwise I'm going to get fired. These are books that in the association field and Board of Directors have been floating around, and so if you're interested in knowing a little more from the perspective of association lingo, what's being said, you might want to take a look at those.

The first one is called Race for Relevance. It's a book written by an executive director, so it definitely has an executive director slant to it. Harrison Coerver and Mary Byers basically make four observations on what's happening today generally for associationso this is MLA and, really, a "we are not alone" kind of ecosystem here:

- That many associations are tradition driven, slow, and risk-averse-and I would say that's something we're comfortable that this is where we're at right now and are looking to change.

- That you expect value, and that companies, our sponsors, and so forth expect a return (people don't actually write checks to support us if they don't feel they're going to get some return; so please do go visit our exhibitors and speak to them).

- That technology enables all of you to get information and to get education anywhere, and so we are in a competitive environment. We should not assume that MLA is the only option, and you know that, to get certain things. Even though we are your association, we are in a competitive environment.

- And, as the average age of an association goes up, it tends to lose relevance. So we have to be very aware about maintaining a constant influx. And thank you, 270 new members, for coming in so that we keep renewing ourselves.

In the book they come up with five priorities. Overall, the governance model and committee operations, in the sense of making them more nimble and faster and so forth - that's certainly an area we're looking at with the board. Empower the chief executive officer (CEO) - I love that one, but don't worry about it, and enhance expertise. They are already big experts, but it's part of a dual system of clarity of roles and making sure not every decision goes up to committees and so forth, and that there's a clarity in governance so that we can be nimble but at the same time follow important governance principles. I think you need to read it that way.

Rigorously define the member market: This is an area that has come up over and over in probably most discussions, and it's who are our membersand I would say, who are our customers. As your roles change, as we're shifting to health information in general, certainly, we're looking beyond the traditional older roles of medical librarians to a broader role, and we need to take that into consideration whether we're doing programs or trying to attract people to come to our annual meeting, or people who come to our website, just to take a few examples.

Rationalize program and services: Think of that as a two-dimensional approach. On one axis, you have the strategic value of a program-how important is this particular program in achieving our mission. The other angle is resource use: how much time does it take in volunteers, staff, out-of-pocket expenses. And certainly, the very strategic programs that don't take much resources, they're great. Wonderful. The ones that aren't very strategic that take a lot of resources, well, you know, maybe we should stop doing those. And the ones that maybe are strategic and taking lots of resources, can we run them a little differently?

You have to think of this analysis as being dynamic. It can't just go strategic because then you'd be doing everything. You've got to have a ranking concept: What's more strategic than something else? Because everything's important, but there are some things that are maybe a little more important. But you have to put the economic aspect and the human resource impact-staff and volunteer-into the picture. You can't look at things in the absolute; you can't just have an accounting approach; and you can't just have a "nice to have" approach.

The last one, of course, is build a robust technology framework. You've heard a lot about this. We're essentially doing that first this year through our MLANET, but also through other initiatives in terms of internal systems, and emails, and Google apps, and you name it, and we'll be looking at such things as our education, and our learning 
management systems, and our experience at the meeting. This is a multiyear project, with probably $50 \%$ of it accomplished this year.

If you look at the priorities, and when Michelle is going to be looking at those strategic priorities, you'll see a lot of connections to those general priorities, with obviously an MLA flavor, since those are general and we have specific situations here.

And so I came up with our own book, which I'm sure many of you have written: The Five Radical Changes for the Profession: The Librarians' Race for Relevance. So we may trademark that one. I just came up with my very candid observations of the environment for the profession. Changes in health care delivery, that's an obvious one. Changes in health information technology, kind of an understatement. Explosion-my staff changed that word to explosion, thought it was more impressiveof ways of getting health information. Changing roles for librarians. And closures of medical libraries, reduction of projects.

You'll notice that most of these words have the word "change" or "explosion." "Closure," "reduction" - those are fairly powerful words. And one of the points I made during my interview - it was like, either I hit it right or they were just going to choose someone else-is that you want all this change. This is great. And every action word, or most action words, in your strategic plan is the word "continue."

I'm saying continue, change, change, continuewhich one is it? And there was a unanimous consent of the board saying, "We want change, we want change." I'm like "All right. I'm your guy if I can convince you. So what's the approach to change?" Here's my second book - and then I'll stop boring you with bullets. This is the last bullet slide. In fact, it is the last slide - that if you haven't read, I think it would be very interesting for you to read. It's also a website. It's by John Kotter, and he has a website called Leading Change, I believe. It's called Why Transformation Efforts Fail. It's from 1995, and all of this remains totally true.

And it's a process that. . I'll just read through it and then I'll give you two examples-one in technology and one in education-about us applying this process. And I'll kind of work with you on that to show you how we're going about doing things.

The first is establishing a sense of urgency. If you don't think there's a problem, why change, right?
You do that with metrics, with evidence, typically, and you don't go around the bush. You say, "Hey, this is a serious situation and this is why." The guiding coalition is the concept that you can't do everything alone. "I want change but the board doesn't" - that's never going to work. You need to be a group of people who believe that in fact this is urgent, that this is the core, and that you're the core team to being the ambassadors and to being that coalition for change, however long it takes. And if you can't convince anyone, then maybe you're wrong; it's not that urgent.

Of course, you have to have a vision and a strategy, a plan-strategic plan and so forthbecause otherwise, you're not quite sure what you're going to do. But you can't have a strategy if you don't have a leading coalition. There's kind of a sequence there. And then you've got to communicate, communicate, communicate. And it's not sequential; you've got to communicate all the time because this is disruptive for people-sacred cows and all of these different things - and you have to explain why and what you're doing and so forth, explain it twenty-one times, most likely, in many situations.

Then you've got to empower action, and you can't just do it yourself; you've got to get a whole momentum of people. In our particular situation, we have committees, and staff, and so forth. People have to be empowered to change. You've got to generate short-term wins, and you've got to celebrate those wins, and you've got to recognize the people who are doing those wins as being really important agents of change.

Then you've got to build on that and consolidate gains, produce more change, until you get the entire project done. The theory here that Kotter has is that when you do all this, and you do it successfully, and you do it several times over, this is when you change culture, as opposed to saying, "This is our culture and decree," and suddenly everybody believes the new culture. And I think if you speak to the staff, certainly, and board members, you will get a sense of how that's happening.

So a couple of examples. The one on technology, where it came and said that, we have a system where we're putting good money after bad money. We'll never get to what we need to do. We have 50 websites; we have 125 email discussion lists. We have this huge diagram. We made this enormous diagram, which some of you who have been on the 
website have seen, and say, this is a problem here. We can't not do something significant.

Not that complicated to get a leading coalition here, whether it's staff or it's the Technical Advisory Committee, whether it's the people on the board saying, "No, you're absolutely right." And then we developed a plan, and we're hopefully-that's the intent of getting something bigger...AND saving money, Mr. Treasurer. . .which then wasn't very hard. And we've been communicating. And the communication is certainly on the blog, in the MLA News. We've had conversations with every single section, so twenty-two conversations, because a lot of that affects sections. We're communicating here, and you will see a lot more of that.

We're empowering sections, and we're empowering all sorts of different groups of people to be part of that project. And the short win is September. That's pretty good. And how are we going to keep going? Well, perhaps with chapters and with other things that are eventually going to gravitate around that.

And by that time, what is the culture we're changing? We're putting you at the center of the experience. We're moving from an MLA-centric approach to an audience-centric approach, and with experience, with you being able to find information, to have your own personal experience, that's going to be different from your colleagues, depending on what you belong to-which sections, committees, task forces, and so forth. And it's going to dramatically change the whole culture of how we go about doing things and building communities at MLA. And so that's a pretty good example.

I'll take a second one, which is in its infancy, which has to do with education. I've been hearing from a lot of you that we have a very robust and excellent quality education offering, and I'm sure that is absolutely true. And so you think, okay, what am I talking about here? Why am I here telling you about a sense of urgency? So my observation, coming from 30,000 feet and looking, is that we are in big need of getting audience-centric education clarity. In other words, if I am a new professional, if I'm coming from this particular area, I actually have a lot of challenges finding out how do I build a curriculum to achieve my professional competencies.

We have $\mathrm{a}-$ and the board is used to me talking like this - a very teacher-centric, educator-centric approach in the sense of, I have this great program and so forth, and it goes out, and it is a great program. But from an audience, in terms of I want to build my professional competencies and go from here to here, I have no idea what that curriculum is. To me, that's an urgent problem here. If we want MLA to be the place people come to figure out what their curriculum is, whether they take MLA classes or refer to educators who teach those classes, the delivery is not the issue here.

We need to figure out how to turn this around; to put you as an individual from a person wanting to have professional development at the center of this equation. And I think we can do a lot better, even though. . in this case, I'm an optimist. If the glass is half empty, I think we can fill it significantly and really put MLA at the center of-even better at being really the reference and your place to go to when you want to plan your professional development, not teacher-centric education. I'm not saying everything needs to be provided by MLA but certainly in terms of building your career.

And we're defining the standards because we're defining the professional competencies. There's a task force working on that, and we should. But then, the standards are used-and I don't mean to say that we're not doing any of this - but I think that we need to develop a vision and strategies. And I'm not explaining why here, because we're not there yet. And to some extent, still a guiding coalition to figure that out. So this is the beginning of the process of discussions that I would be having with committees and boards where that entire rollout is not there. This is a three- to five-year program. So two examples of methods of how we work, and certainly I would be glad to share more and more detail on these.

And now, for something completely different, we want to open and hear from you-this is a dangerous effort-as an open town hall. So I suspect you're not that angry though. The picture on the left says, "Standing together for health," which I thought was hilarious. And they're choking each other, a lot of angry white men. So instead of that photo, I'm going to put a smiley face and open it for questions.

We have about ten minutes for some questions before we have to wrap up the meeting. So I may refer to "Ask me next year," "Ask Linda," "Ask Michelle," and so on, but on some of them, hopefully, I can speak, so please feel free, or we'll be done early. There are microphones, and so since the session is recorded, we certainly would appreciate you speaking into the microphone. 
Audience member: I have a question about the reference you made to curriculum in the future, and I wanted to hear your vision for how the Medical Library Association is going to collaborate/work with the National Network of Libraries of Medicine or National Library of Medicine in general for providing continuing education training, things like that.

Kevin Baliozian: Right. So I think collaboration has always been and will always remain a very important part of how we provide education. We're in our infancy right now. Think of two things we're doing at the same time. We're reevaluatingupdating is probably the best word-our professional competencies, and we're also analyzing audiences. And then we are going to combine those two things and figure out what we should be teaching to whom in general; what should be taught to whom in general. Because we can't teach everything to everyone, so we can't have every one of these squares. That's just unrealistic.

Some of those squares would be better filled by maybe some core curriculum that we may offer; others by the regional library, others by chapters, others at the annual meeting. Delivery and instructional design is going to be a big part of how giving that curriculum would differ. Teaching current issues is going to be very different than teaching the basis of setting up an evidence-based practice. Does that answer your question?

Audience member: Yes, thank you.

Second audience member: I'm Joanne Gard Marshall, AHIP, FMLA. I'm from the University of North Carolina. Welcome. We're really glad that you're with us. One thing I wondered if you'd considered is that we do have a framework called the Academy of Health Information Professionals, which was envisioned as something, if I hear you correctly, of what you were thinking, a tool to help people build their own continuing education (CE). And it was much more flexible than just taking CE courses. Many other things count, like writing an article or being involved in committees and in MLA and in the profession generally.

And I was wondering if you were considering how we could use this tool. I think we've had some trouble in some ways really getting it going and having it have a meaningful result, but I don't think that means that it isn't really a useful thing that we could continue to look at in the context of these changes.
Kevin Baliozian: Great question on the academy, and thank you for bringing the academy up. The credentialing program is a really important part of any professional association, and it's great to come into one that has such a strong one. It's an experience-based one. It used to be exam-based a long time ago. One general observation is, organizations tend to be siloed, so when you think about education, certainly the academy is part of it. The annual meeting is part of it, the pre-conference is part of it, the CE offerings are part of, the offerings that are offered by educators outside of MLA - say, the MLA Educational Clearinghouse-that's part of it. Mentoring, that's part of it. And we have committees involving all these separate things. And then how do these things get connected, right?

And that's true of just about everything we do. We're very comfortable when it's in a committee or in a section. And so part of the change of approachand it's a dramatic approach, and I'm sure Michelle will touch on this when she does her address-is, when we do our strategic goals, we put them at a high level that goes across all those siloes to create all those alignments. So it's a really big matrix environment, and you all know about matrix environments and how difficult they are to manage.

So thinking through the academy, as we think through curriculum, as we think through the annual meeting, as we think through how do you get CE courses from outside of MLA that may be valuable to certain audiences, such as nurses, who made need some education in health information or disaster information-those types of things; and maybe we should be offering continuing nursing education (CNE) - those types of things. We do need to comprehensively look at this to have a cohesive approach.

Now, I don't know the detailed answers, and I'm not a specialist on any one of those areas, but I do know that our approach needs to be global in terms of the various components of education and clearly audience-centric, as well, as I mentioned. Thank you for the question.

Next audience member: Hi, I'm Jeanne Burke and I'm from Creighton University in Omaha. In the past, I have done some teaching in professional organizations at the behest of NLM, and I was wondering if we could expand on that model and start reaching out to the other health care professional bodies and just offer more of our 
training and expertise as a way of opening dialogue about who we are and what we do.

Kevin Baliozian: So this is when I say, four months, two days. I'm hearing what you're saying, and I don't know, personally. I'm sure others have points of view, but these are the types of things we need to look at. Ask me next year. I'm sorry. That's the first time to do this. How many joker cards do I get? So you're very disappointed in my non-answer, but I really am not equipped to give you a good answer on that; I'm sorry.

Audience member: Well, you don't have to have an answer. Just put it in the future reference.

Kevin Baliozian: All right, duly noted. Recorded and noted. No, thank you so much. This is really important input. That's the idea of why we want this session. It's not just to hear what I have to say but to hear what you have to say.

Next audience member: James Shedlock, AHIP, FMLA, retiree, Chicago, Illinois. I was really fascinated by your personal history, and I appreciate your sharing it. So my question goes to a little bit more detail about your thinking on why you switched from leaving the photography industry, for example, and why you chose health care association management. Why not education, or architecture, or poetry, or something? Why health association management?

Kevin Baliozian: Thanks. There are a few anecdotes about that, and I won't bore all of you. But there's a little intermediary element here that I didn't mention. So after selling our business, I was looking for a job for the first time in my life after twenty-two years in the family business. And you can't find the same type of job. I was the CEO of a family-owned business. How do you do that somewhere else? It just doesn't really work. I needed to leave photography. That was a big decision. Even though I loved it, and I can lecture on lighting, and colors, and spectrums, and stuff for hours and love it-you've seen me take pictures-I had to leave that industry.

And I fell into the nonprofit area. I got a phone call from the largest Armenian nonprofit, and their rationale for bringing me in, other than I'm Armenian, is that associations are like family businesses; they're both totally dysfunctional. And I'm quoting. In their case, it was absolutely true. So I went there for three years, and this was in Paris. Even though it's a New York business association, I was the European director. And I worked and learned, and I caught the bug. I love working in the nonprofit area. This was cultural and humanitarian, and we had theatres, and summer camps, and chapters with choral groups.

Then my wife sent me an email with bullets, and I have reproduced it, about all the reasons that we should move back to Chicago. And this was in February 2007. I remember it well, and I'm like "Okay." No job, no school, no house, limited finances-maybe six months. Let's do this. So then I went to Chicago, and I interviewed with Smith Bucklin. Smith Bucklin is a very large association management company that runs associations, instead of associations having their own staff. The typical association is much smaller than MLA.

And in fact, they hired me. Can you believe it? They hired me, and then they stuck me in the health care area. So that wasn't even my choice. I needed a job. So I went in there, and then I loved it. And I ran four different health care organizations and two scientific societies - one, the International Bone and Mineral Society, the other one, the International Society for Experimental Hematology.

I learned a tremendous amount about publishing from the society side, negotiated kickass deals with both Nature and Elsevier, if you can believe it. . taking their money. Charged exorbitant amounts, most likely to libraries. I don't know those details. No, but certainly developed an entire thing around there. I worked for a nurse group-the Legal Nurse Consultants - so that was a much more pleasant experience than working with physicians and worked with hospital administrators for another group.

After six years, I pretty much decided I wanted to focus on one organization and wanted to really go very deep into that and no longer work for an intermediary company, and this is where the fit with MLA just happened at the right time. So I officially have health care now here.

President Walton: Tell them about your journal.

Kevin Baliozian: Oh, yeah, BoneKey Reports-I have an emotional attachment to it. It was a launch. We got it into PubMed and MEDLINE, and we're going to get an impact factor at the end of the year. "We" - I still own it, so subscribe to it. Just kidding. I have no vested interest other than emotional. Thank you for your question.

Next audience member: My name is Mark Folmsbee. I'm an old law librarian actually new to 
the profession in MLA, but I wanted to take a moment to share an observation. One of the things that's striking as I've come to meet many of you and have already created great friendships, I think, is how medical librarians and the libraries themselves have jumped into electronics and technology in incredibly fancy ways and doing cool things. But there's part of a library that is the physical presence, the bricks and mortar.

And I'm kind of surprised by the extent to which I see comparing law libraries to medical libraries, and perhaps in other areas as well-the lack of that ability to retain the bricks and mortar. And I wonder if the association can provide a role in some form to help those of us who now, in the profession-I'm one of the new guys-maintain bricks and mortar and provide that collaborative environment for our students, and doctors, and everyone else who comes in to learn, rather than just do everything electronically.

So maybe it's a challenge. Part of me thinks we should just throw down and say there's a piece of a library that we should hold onto, a presence.

Kevin Baliozian: I must say, in preparing for my interview, I did connect with people in master's programs. I met Kristi L. Holmes. I just cold-called her at Northwestern, saying, "Hey, I'm applying for this job." I didn't even know who Kristi Holmes was. Pretty nice lady. And she invited me, and I visited the library. I think the last time I visited the library was in college. And my first reaction was, "Wow, there are no books there." And that's true.

There are a lot of parallels going on with the legal law libraries as well. In fact, there's a kind of group of us of executive directors and legal law libraries, theological libraries, and so forth; we hang out together for lunch every few months, and we compare notes about what's going on. And we're ahead here, and they're ahead there in terms of change, and indeed, they're going through the same changes.

I appreciate the emotional attachment. I have none because I'm just totally nonemotional. No-I've just come into this field. I get it. But I haven't drunk the Kool-Aid. I have the ability still to detach myself and look at things a little more, I guess-without that legacy aspect, even though I understand how important history is, and in fact, I do appreciate that and I find that important. That's why I have Mary Langman, who gives me context on everything.
But I don't think it changes what we need to do, I guess is what I'm saying, from at least the standpoint of my role as executive director and putting together and driving new strategies on education.

We probably have time for just one small question, and then we need to wrap up. And if there are none, that's great. Well, thank you very much. I appreciate the dialogue. Please continue.

President Walton returned to the podium and moved on to the annual report. In the interest of time, annual reports were received in a block. The informational reports of the appointed officials, the councils, committees, task forces, representatives, sections, and chapters are found in the 2014/15 Annual Report of the Medical Library Association. These reports are available on MLANET and will remain there throughout the year. They are also available in paper copy from the executive director's office. There being no corrections or objections from the members, the reports were filed as presented.

President Walton concluded Business Meeting 1 and reminded attendees that Business Meeting 2 would be held on Tuesday, May 19, at 9:00 a.m.

\section{BUSINESS MEETING 2, PRESIDENTIAL INAUGURAL ADDRESS, AND MLA '16 INVITATION}

\section{Tuesday, May 19, 2015}

President Linda Walton, AHIP, welcomed everyone to MLA Business Meeting 2 at 9:00 a.m. A quorum of voting members was present.

She then recognized and thanked retiring MLA Board Members Julia Esparza, AHIP; Teresa L. Knott, AHIP; and Chris Shaffer, AHIP, and presented them with certificates as a token of respect and gratitude for work well done. President Walton also expressed her gratitude to Dixie A. Jones, MLA president during the 2013/14 association year. Highlighting some of Jones's initiatives, President Walton presented a plaque to Past President Jones for a job well done.

President Walton then introduced the new members of the MLA Board of Directors: Teresa L. Knott, president-elect; Melissa L. Rethlefson, AHIP, director; Chris Shaffer, AHIP, director; and Lisa K. Traditi, AHIP, director.

Michelle Kraft, AHIP, then presented outgoing President Walton with the Presidential Cup and 
congratulated her for a year when under her leadership MLA broadened its opportunities to build its future.

President Walton next introduced 2015/16 MLA President Michelle Kraft, AHIP, who delivered her inaugural address.

\section{INAUGURAL ADDRESS}

Michelle Kraft, AHIP: Thank you, everybody. Well, in keeping with the space theme, I thought I'd start things off with a little video, so let's start the video.

Now, I'd like to say that I had that all planned with Mae Jemison and everything, but honestly, it was just really cool to do.

You can't stop change any more than you can stop the sun from setting. And that is a really cool quote. Unfortunately it came from one of the worst Star Wars movies ever made. And I promise this is the only reference to the Phantom Menace. Mark E. Funk, AHIP, FMLA, wherever you are, you begged me not to put in Jar Jar Binks. Don't worry, there's no Jar Jar Binks.

But it's true: you can't stop change any more than you can stop the sun from setting. MLA librarians, libraries, we have a lot of changes going on. Like the sun is always setting, change is always going to happen, so it's best we have a plan. And thankfully, we are not going up against the Death Star. But the news is, if we did, we would not have to hide and smuggle in a robot; we could go to Amazon and get it.

But MLA does need a plan. So this is MLA's strategic plan, and it kind of looks a little complex and everything. But thankfully, I mapped it out in a way that we can all understand. I made it a rocket to fit with the theme. And clearly, it's such a good thing that I'm a librarian, because I would not get a job as an artist with Lucasfilm. I think they might take a dim view of my design skills there.

But it's a good way of illustrating how the plan fits in with our thing here at MLA. We've got the front nose of the rocket ship, and that's our mission. Then there's our vision, our values, our mission statement. The middle part of the rocket is our flight plan and our star charts, our navigation. That's where our high priorities are, our strategic goals, and our strategies. And then the fuel is our objectives and our metrics. The objectives get us there; the metrics tell us when we're there.
So now you have MLA's plan. Let's throw up the hood on the ship, have a look inside each part a little bit more and see how it goes. So the mission control. This is MLA's mission, our overall reason for jumping on that ship and blasting off. It's a little lofty, but you need a lofty, good reason to actually blast off into space. You do! Well, as Mae Jemison already said, we've got a lot of things we've got to consider: food, clothing. I mean, you have to have a lofty plan to even decide you're going to eat bugs forever in your lifetime.

MLA is dedicated to the support of health sciences, research, education, and patient care. That is our mission. We foster excellence in achievement and leadership of health sciences and library information professionals to enhance the quality of health care, education, and research. That is the core of why we're here. That is the plan. That is what's driving our goal of jumping onto that rocket ship.

So what does MLA do? This is our action plan; these are our flight plans. The action plans are our flight plans. These are our high-priority areas. This is what we program into R2D2 so that we don't get lost on our mission. And what MLA does, new professionals in education and MLA technology, are the action plans of our high-priority items right now for our strategic plan.

We'll go a little bit into what MLA does. MLA rationalizes programs and services, and streamlines and clarifies organizational structure. Our programs need to be strategic to the members. We need to speed up decision making. Have you ever noticed how long it takes to get things done here? We are as slow as a sand crawler that is here in this image. People wait and do things as the annual meeting comes around. I think we need to change those things up a little bit.

We need to meet more than once a year-and I don't mean MLA as a group, but virtually, online. We need to work together as a group online. We must accomplish things throughout the year to be relevant to our members, especially the members who can't always come to the annual meeting every year. We need to maintain and improve our MLA financial health. We don't want to end up like the Jawas, living like scavenged robots. We need other revenue alternatives.

We also need to simplify. We have 1 Board of Directors, 29 juries, 2 editorial boards, 2 councils, 5 task forces, 8 reps to international allied organizations, 19 reps to US-allied organizations, 22 committees, 22 
sections, 24 SIGs - but we just got more SIGs - 50 websites, 115 email discussion lists, and 150 pages of annual reports - and that's only because not everybody sent their annual reports in on time.

We are a big organization that seems to have the nimbleness of an AT-AT. We need to maybe simplify things a little bit more so that through processes and understanding of procedures, groups can work together. We're no longer in siloes.

We also need to work to provide things for our new professionals. We need to align our programs and services and governance with new professional members' needs and expectations. We need to support those new professionals in the development of their careers. We need increased use of MLA programs. Bring the new professionals into the MLA programs and services - the groups, the sections, the SIGs, the chapters - all of those kinds of things. The new members are looking for other members to be colleagues and give professional guidance. We need to really support bringing them in as a group or as individuals.

We also want to strengthen our education and for that I think of the Jedi Experience Academy. I really like this thing. Thank you. And it really makes sounds when you swing it. We need to strengthen MLA's educational curriculum and offerings. My daughter represents the new professional, in my mind. She is swinging away her little heart at Darth Vader. When we went to Disney World this spring break, I took my kids and they got to do the Jedi Experience Academy, where they got to learn to be a Jedi and battle Darth Vader.

At first, we were a little concerned; she's four. We were afraid she would spook out at Darth Vader. We should not have been concerned. She went to town swinging away at Darth Vader. And it's a lot like the new professionals: they are swinging away, they are going to town. They have some of the most energized ideas. We need to update our core competencies to support those ideas and to keep them swinging away. We need to meet their expectations via design and delivery so that they can keep swinging away at Darth Vader.

So this is my middle son. He is the mid-career librarian. And he was a little more methodical in his approach. He listened to the Jedi instructor. When the Jedi instructor said, "Swing high," he swung high; "Swing low," he swung low. And he used those CEs for when he was unable to attend those meetings to attack Darth Vader. We need to have those CEs available to our mid-career librarians that help our mid-career librarians attain their Jedi experience. We need to develop an MLA intellectual property. We need to be the owners of some of our best examples of education.

You all know I have three kids, so here's the last one. This is Pete. This is my oldest child, and he represents the seasoned professional. And he's only twelve, and he's taller than the actual Jedi master. But we need to position MLA for our seasoned professionals as well as our incoming professionals and our mid-career professionals to be the educational resource for all medical librarians. We need to also grow revenues outside of the membership and the annual meeting.

And for him, the seasoned professional? Yes, he listened to the Jedi master and swung up, swung down, as my middle child. But as the oldest, he improved. So he used both the new Jedi, or new Padawan, like my youngest child Rachel, and really attacked, but he used the skills he learned as a midcareer librarian, and then he took it and tweaked it as a seasoned career librarian to adjust his attack and strategy on Darth Vader.

We also need to look at our technology. We need to transform MLA's communications systems, and we're already on that path. We need to improve the user experience and the user interface. We want the platform to be agnostic so whether you're on an iPad, an iPhone, an Android, your laptop, whatever you're on, you see an MLANET that works for you.

We also want MLA to be at the forefront of content delivery. We want e-content delivery information to members as well as nonmembers - for example, the consumer health information. We want all of that information easily found on our platform. And we're on our way toward that.

We want the same look and feel across MLA groups, so your chapters, your sections, your other groups, we'd like to bring you onto the MLA platform so that you have the same look and feel, so people have the same sense of community and group with MLA. We want to grow the online communities. Growing the communities is engagement.

And I said this earlier in the meeting: if you aren't out touching your members - and I don't mean physically - they will not be engaged. The number one reason people leave is they aren't engaged. If you lose their engagement, they lose value in your 
association, your section, your chapter. So you need to engage them; you need to reach out and touch them.

Our hope is that our technology will be a great tool to help with engaging members. It isn't going to be the end-all, be-all. It's up to you to use the technology to engage members, but without the technology, it becomes difficult. We hope that we will improve our technology to make this easier and better for you to engage them.

So those are our high-priority items that we are currently working on. But like all rocket ships, once you've hit the next leg of your mission, you need to replace it with the next set of instructions, the next leg of directions, the next priority. And I kind of show that with one of the priorities dropping off. It's not jettisoned like space junk, because our hope is that we have set up the systems so that the priority lives on in our everyday MLA lives. But it's easier to explain it with a dotted line and jettisoning it.

Research and advocacy is going to be our next priority coming into the spaceship. Even Jedis had a library and conducted research for their colleagues to use. We want to support and advance health information research and practice and advocate the value and impact and the benefits of health sciences libraries and librarians. Basically, I'm summing it up as this: research to support advocacy.

If we want to strengthen professional development, we need to create a curriculum to foster research skills. We want to enhance access to evidence-based practice resources and tools that amplify the value and impact. The great thing is that the Hospital Libraries Section already has a great start on this. I'd like to include similar tools for academic libraries and house them in an area for everybody to be able to use those tools to research their value and use those to prove their value to their administration.

An organization can only advocate so much on behalf of its members. If its members don't advocate on their own behalf, we cannot help the individual person. It's up to the individual to use our tools to advocate for themselves. We can only advocate as a whole.

We also want to provide support for increased research. We want to find grants on not only doing research, but also teaching how to do research. Workshops - for example, is it the South Central Chapter that has a successful writing workshop? Why not reproduce a similar type of thing but for research?
We want to advocate champions and promote the importance of it in evidence-based practice to health information research members and to the stakeholders. Not only do we want to advocate to ourselves-which is important because people can learn from each other and take the research one person has done and apply it in their institutions to advocate for themselves-but we also want to increase our advocacy efforts and preach to our stakeholders. And you can't advocate very well if you don't have the research to back it up. And we'd like to publish it in areas where our stakeholders read. I don't mean publish always, necessarily, in the idea of traditional journals but avenues that our other stakeholders look at.

So why is this important? Because we are a larger health care universe. We are one of those little worlds up there of librarianship. There are other worlds that we need to strengthen our ambassador ties or our liaisons with. For example, the Joint Commission world has been an interesting world. It's not exactly a hostile planet, but they don't always see things the way we do. And that's because they have other ambassadors and liaisons who are also on their world.

Right now, we are working to nominate two people. The Joint Commission came to us-and I'm sure they came to other organizations as welladvertising that they had one seat open for a public member of their board. We've sent in two nominations to be considered for that one seat for the public member seat. So we are advocating and working with our liaisons on the Joint Commission.

We are also taking an around-the-brick-wall kind of approach with Joint Commission. I know that Joint Commission has said, "Thou shalt not put 'library' or 'librarian' in their standards whatsoever." That is a dead horse. Actually, should I make that like a spaceship? That is a dead, drifting spaceship. It isn't coming back. But with our liaison, we are fighting to go around that standard by actually working and creating a metric for Joint Commission to better score the access to information. We should be in charge of our metrics, and this is a way of giving Joint Commission a way to look at how people access information, and that we are working toward.

But there are other worlds we need to strengthen or continue our relationships with: American Nurses Credentialing Center (ANCC), the Magnet status, and other nursing credentials. We need to make sure that we still have ambassadors to that planet. The 
Liaison Committee on Medical Education (LCME) for medical education, all of these groups, and many more, have very strong ties with libraries or use of libraries as part of their standardization, and we need to make sure we continue to have a presence, an ambassadorship, in their programs to keep their standards strong.

That's because there's always another way around. We always have other planets that we need to visit, and there are always other planets that need to visit us. By keeping those ambassadorship relationships open, hopefully we'll have more people looking at our planet of librarianship.

We don't want any clones. Diverse people with diverse ideas - there's more than one way to skin a cat. I don't know how to make that a space thing. Without having a diverse group of people with diverse ideas, we won't know ways to go around those brick walls; it won't open to us ideas for alternatives, other ways to accomplish things.

We need a diverse group of people to get engaged. That's why I encourage everybody, back in our previous slide, to engage members. It is up to you to engage the new members, all members, so that we have a diverse group of people, so that we don't have to worry about having one single mind as to how we approach things. A diverse group of people can approach it from many different ways, and we can look at all different ways of going forward.

It's all about action and engagement, and I really, really tried not to put Jean Luc Picard saying "Engage" on here. But that would be mixing my Star Wars and Star Trek, and we know we can't do that. So I had us going into hyperspace. But it's all about engagement and action. This is your MLA. Your actions and your sections, chapters, communities, committees, SIGs provide the fuel that move us forward. We can't go anywhere. Without your actions, without your engagement, we are floating in space. We aren't going anywhere without you.

That means you need to connect via community, individuals. Network, brainstorm, share information, work together as a group to move us forward. As we go on our action plans, we will be going out and asking a lot of different groups to take ownership of certain action plans.

It will be very interesting, because one action plan isn't going to be owned by one group; it is parts of people, and sections, and SIGs, and chapters, and communities that are going to be part of every piece of those action plans. And without them participating, that action plan will fail, will be left floating in space. So we need you, and your action, and your engagement to move us forward. It is your MLA. You are the fuel. You are the reason we are moving forward.

I'm going to leave it with this: we must succeed. There is no trying. Do or do not. There is no trying. We will succeed. If we as a group work together, engage everybody, look at our action plan, and adjust as necessary, we will succeed. And as Master Yoda said, "Do or do not. There is no try." Thank you.

At the conclusion of her inaugural address, President Kraft asked Anne K. Seymour and Jeff Mason, cochairs of the 2016 Joint Medical Library Association (MLA), Canadian Health Libraries Association/Association des bibliothèques de la santé du Canada (CHLA/ABSC), and International Clinical Librarian Conference (ICLC) meeting to come to the podium to give the official thank you for the 2015 annual meeting.

Jeff Mason: Anne, we need to thank a lot of people for this great meeting in Austin.

Anne Seymour: I know, Jeff. Our mothers taught us well, and, you know, we need to handwrite some thank-you notes.

Jeff Mason: Let's get started. Dave, can we have a little thank-you note music?

Anne Seymour: Dear 2015 National Program Committee, thank you for providing an amazing program for MLA in Austin. All attendees we've spoken to have been inspired by the speakers and all the innovative and creative work of our colleagues.

Jeff Mason: Dear Local Assistance Committee, thank you for hosting us in your weird city. We've had lots of tasty Tex-Mex barbeque. I actually had a meal that was only meat. We had fun visiting all sorts of great places, listening to music, and partying with bats, friends, colleagues, and vendors.

Anne Seymour: Dear MLA headquarters staff, as always, you have planned and run a terrific meeting. We thank you for all your hard work and effort. It's really paid off.

Jeff Mason: Therefore, be it resolved that the membership of the Medical Library Association extends its profound appreciation and gratitude to the 2015 National Program Committee, Local Assistance Committee, exhibitors, sponsors, the 
medical librarians and people of Austin, and the MLA headquarters staff for this excellent meeting and providing us with limitless possibilities for an outstanding joint meeting in Toronto in May of 2016.

President Kraft then recognized Anne Seymour, Jeff Mason, Sara Sutton of ICLC, the 2016 Joint Program Committee, and Vanessa Kitchin, cochair, 2016 Local Assistance Committee, to invite members to the 2016 Annual Meeting in Toronto.

At the conclusion of the invitation, President Kraft recognized Sandra Franklin, 2015/16 secretary of the MLA Board of Directors, who moved to adjourn the meeting. The motion carried and the second business meeting of the 115th annual meeting was officially adjourned.

\section{SECTION PROGRAMMING}

Section programs were presented in four time slots: Sunday, May 17, 4:30 p.m.-5:55 p.m.; Monday, May 18, 10:30 a.m.-11:55 a.m., and 3:00 p.m. $-4: 25$ p.m.; and Tuesday, May 19, 3:00 p.m.-4:25 p.m. Paper abstracts that were scheduled to be presented are available at http://eventscribe.com/2015/mla/assets/ SectionPrograms.pdf. The final version of the abstracts reflecting only those presented at the meeting is included as an online-only supplemental file to the January 2016 issue of the Journal of the Medical Library Association (JMLA).

\section{POSTER SESSIONS}

Poster sessions were presented in two time slots: Sunday, May 17, 2;00 p.m.-2:55 p.m., and Tuesday, May 19, 1:00 p.m.-1:55 p.m. Section and chapter posters were presented on Sunday, May 17, 2:00 p.m.-2:55 p.m. Poster abstracts that were scheduled to be presented are available at http://www. eventscribe.com/2015/mla/assets/PosterAbstracts. pdf. The final version of the abstracts reflecting only those posters presented at the meeting is included as an online-only supplemental file to the January 2016 issue of the JMLA. The actual posters are online in the MLA Itinerary Planner.

\section{OTHER MEETINGS AND EVENTS}

\section{Pre-meeting activities}

On Thursday, May 14, the following meetings were held: NN/LM Web DevConf and MLA Board of
Directors. On Friday, May 15, the MLA Board of Directors and Credentialing Committee met and the following informal meetings were held: NN/LM consumer health coordinators; NN/LM outreach coordinators; NN/LM Regional Medical Library directors and associate directors; NN/LM Regional Medical Library All Hands Meeting and Applying for Regional Medical Libraries Cooperative Agreements; and NN/LM Joint Session consumer health and outreach coordinators. On Saturday, May 16, the following groups met: 2016 Joint MLA/ CHLA/ABSC/ICLC Planning Committee; 2016 program planners; Ad Hoc Committee to Review Core Clinical Journals; chairs, presidents, and allied representatives orientation with chapter breakout and section breakout; Chapter Council; Chapter Council/Section Council; Nominating Committee; and Section Council, The NLM/AAHSL Leadership Fellows Institute informal meeting took place.

\section{Sunday, May 17}

On Sunday, May 17, these groups, sections, and SIGs met: African American Medical Librarians Alliance SIG; Cancer Librarians Section; chapter treasurers orientation; Corporate Information Services Section; Department of Veterans Affairs Librarians SIG; Federal Libraries Section; Fellows of MLA; Health Association Libraries Section; Informationist SIG; Institutional Animal Care and Use SIG; International Cooperation Section; Journal of the Medical Library Association Editorial Board; Latino SIG; Libraries in Curriculum SIG; Nursing and Allied Health Resources Section (executive board); Pediatric Libraries SIG; Planning Awesome Chapter Meetings; Relevant Issues Section; and Research Award Poster and Paper Judging Instruction. Exhibitor meetings included: EOS Seminar and EBSCO Publishing Lunch \& Learn.

\section{Monday, May 18}

On Monday, May 18, the following groups, sections, and SIGs met: 2017 National Program Committee; Awards Committee; Books Panel; Clinical Librarians and Evidence-Based Health Care SIG; Collection Development Section (business meeting and executive board); Complementary and Alternative Medicine SIG; Consumer and Patient Health Information Section (executive board); Dental Section; Educational Media and Technologies Section; Governmental Relations Committee; History 
of the Health Sciences Section; Hospital Libraries Section (executive board, business meeting, and ice cream social); Interprofessional Education SIG; Lesbian, Gay, Bisexual, and Transgendered Health Science Librarians SIG; Medical Library Group of Southern California and Arizona; Midwest Chapter (executive committee); Molecular Biology and Genomics SIG; Nursing and Allied Health Resources Section (business meeting); Osteopathic Libraries SIG; Outreach and Marketing SIG; Pharmacy and Drug Information Section; Public Health/Health Administration Section; Public Services Section; Revitalizing the Research Imperative Task Force; Rising Stars Committee; Scholarly Communications Committee; section continuing education chairs; Southern Chapter (executive committee); Systematic Reviews SIG; Technology Advisory Committee; Translational Sciences Collaboration SIG; Veterinary Medical Libraries Section (informal meeting); and Vision Sciences SIG.

\section{Tuesday, May 19}

On Tuesday, May 19, the following groups, sections, and SIGs met: Bylaws Committee; chapter continuing education chairs; Consumer and Patient Health Information Section (business meeting); Department of Veterans Affairs Librarians SIG; Joseph Leiter NLM/MLA Lectureship Committee; Leadership and Management Section; Librarians without Borders ${ }^{\circledR}$ Advisory Committee; Medical Informatics Section; Medical Library Education Section; Membership Committee; MLA News Editorial Board; Professional Recruitment and Retention Committee; Research Section; Resource Sharing SIG; section treasurers orientation; Task Force to Review MLA's Competencies for Lifelong Learning and Professional Success; Technical Services Section; and Veterinary Medical Libraries Section (business meeting). Informal meetings included: MLA book authors and prospective authors gathering and Interagency Council on Information Resources in Nursing (ICIRN) Membership Meeting.

\section{Wednesday, May 20}

On Wednesday, May 20, the following groups, sections, and SIGs met: 2016 program planners; Continuing Education Committee; Grants and Scholarships Committee; Oral History Committee;
Strategic Priorities Task Force; and MLA Board of Directors.

\section{OPEN FORUMS}

Three open forums were held concurrently on Monday, May 18, from 2:00 p.m.-2:55 p.m.:

- Around the World in Sixty Minutes

- Redesigning MLA: Sections and SIGs

- Revitalizing the Professional Competencies for Lifelong Learning

\section{NATIONAL LIBRARY OF MEDICINE UPDATE}

Betsy L. Humphreys, FMLA, acting director, National Library of Medicine (NLM), began the NLM Update, "Expanding into the 'Adjacent Possible," " which took place on Tuesday, May 19, from 10:30 a.m.-11:25 a.m., with a tribute to Dr. Donald A. B. Lindberg, NLM director, 1984-2015. She then discussed the NLM Working Group of the Advisory Committee to the National Institutes of Health (NIH) Director whose charge is to review NLM's mission, organization, and programmatic priorities and to articulate a strategic vision to ensure that NLM remains an international leader in biomedical and health information. Ms. Humphreys went on to discuss an obvious "adjacent possible" with organizing, archiving, and providing access to research data; the push for broad data sharing across all domains; and NIH's plan for digital scientific data.

Joyce Backus, associate director for library operations, then discussed a variety of topics, including how NLM has responded to needs over the last year, such as the Emergency Access Initiative and Ebola information; resource sharing; updates on MEDLINE, PubMed, and PMC; metadata and the Bibliographic Framework Initiative (BIBFRAME) to replace the MARC format and develop a core vocabulary; responsive web design and mobile features for MedlinePlus, AIDSinfo, PHPartners, DailyMed, and PubMed Mobile; a learning resource database that brings together all of NLM's learning resources in one place at learn.nlm.nih.gov; changes for the National Network of Libraries of Medicine; collections and exhibitions; and staff news and the federal hiring program, Pathways for Recent Graduates.

Ms. Humphreys concluded the NLM update with a Q\&A session. 


\section{LEGISLATIVE UPDATE}

The Legislative Update was held on Tuesday, May 19, from 1:00 p.m.-1:55 p.m., and was moderated by Linda Hasman, chair, MLA Governmental Relations Committee. Committee members provided an overview of health funding, efforts to expand the National Institutes of Health public policy to other federal agencies, and other relevant issues.

\section{OTHER SPECIAL EVENTS AND RECEPTIONS}

\section{Saturday, May 16}

- Welcome Reception and Opening of the Hall of Exhibits, 5:30 p.m.-7:30 p.m.

\section{Sunday, May 17}

- New Members/First-Time Attendees Program, 7:00 a.m.-8:55 a.m.

- Sunrise Yoga, 7:30 a.m.-8:30 a.m.

- Chapter Council Presents Chapter Sharing Roundtables Luncheon, noon-1:55 p.m.

- International Visitors Reception, 6:00 p.m.-7:00 p.m.

- Library School Reunion, 6:00 p.m.-7:00 p.m.

\section{Monday, May 18}

- Academy of Health Information Professionals Q\&A Session, 1:30 p.m.-2:30 p.m.

\section{Tuesday, May 19}

- MLA in Monte Carlo, 7:30 p.m.-10:00 p.m.

\section{SUNRISE SEMINARS}

Exhibitors held Sunrise Seminars to provide information and to introduce new products and services. The following seminars were held:

\section{Sunday, May 17}

- DynaMed Plus

- Thieme e-Suites: Multimedia Platforms in Clinical Medicine

- Unleashing the Value of Grey Literature in Research Practice
Monday, May 18

- American Psychological Association (APA) Sunrise Seminar

- EBSCO Discovery Service for Hospitals and Medical Schools

- An "Inside/Outside" Look at Cochrane: Update from Carol Lefebvre

- A Unique Method for Fast, High-Quality Systematic Searching

\section{TECHNOLOGY SHOWCASES}

Nine Technology Showcases were held throughout Sunday and Monday:

- R2 Digital Library

- PlumX

- Serials Management and e-Packages

- The AccessMedicine Collections: New Approach to Reference, Research, and Curricular Instruction

- Nursing Reference Center Plus

- Nutrition Reference Center

- Seamless Single Sign-on to Resources Is a Reality

- From e-Journals to e-Neuro: Thieme's Online Clincial Resources

- Medical Test Prep

\section{CONTINUING EDUCATION COURSES}

The 2014/15 Continuing Education Committee offered the following courses to 283 attendees on May 15, 16, and 20, 2015.

Friday, May 15

CE100, Copyright for Health Sciences Librarians, Instructor: Anne Gilliland, scholarly communications officer, University of North Carolina-Chapel Hill

CE200, How to Set Up a Clinical Librarian Program at Your Institution, Instructors: Emily Brennan, informationist, Library, Medical University of South Carolina-Charleston; Michele Klein Fedyshin, AHIP, reference librarian, Falk Library of the Health Sciences, University of Pittsburgh, Pittsburgh, PA; Brandi Detofsky, AHIP, assistant medical librarian, Nemours/A.I. DuPont Hospital for Children, Wilmington, DE; and Amy Allison, AHIP, head, Clinical Informationist Services, Woodruff Health Sciences Center Library, Emory University, Atlanta, GA 
CE202, A Seat at the Table: Working with Local Responders, Instructors: Rebecca Hamilton, state librarian, and Diane Brown, deputy state librarian, State Library of Louisiana-Baton Rouge

CE300, Closing the Gap in Identifying Clinical Trials for Systematic Reviews: Searching Trials Registers and Regulatory Agency Websites, Instructors: Julie Glanville, associate director, York Health Economics Consortium, University of York, York, United Kingdom, and Carol Lefebvre, independent information consultant, Lefebvre Associates, Oxford, United Kingdom

CE500, Information Anywhere: Mobile Technology, Libraries, and mHealth, Instructor: Emily J. Hurst, AHIP, head, Research and Technology, Tompkins-McCaw Library for the Health Sciences, Virginia Commonwealth University-Richmond

CE600, Expand Your Library Instruction Toolkit: Introduction to Online and Distance Learning Support, Instructors: Virginia Pannabecker, AHIP, life science and scholarly communication librarian, University Libraries, Virginia Tech-Blacksburg, and Margaret Hoogland, distance support librarian, A.T. Still Memorial Library, A.T. Still University of the Health Sciences, Kirksville, MO

CE700, Introduction to Genomic Data Repositories and Data Analysis Resources, Instructor: Megan Laurance, research informationist, Library and Center for Knowledge Management, University of California-San Francisco

CE701, Research for Hospital Librarians, Instructor: Heather N. Holmes, AHIP, clinical informationist, Medical Library, Summa Health System, Akron City and St. Thomas Hospitals, Akron, $\mathrm{OH}$

CE702, Library Statistics: Data Analysis for Librarians, Instructor: Jin Wu, emerging technologies librarian, Norris Medical Library, University of Southern California-Los Angeles

\section{Saturday, May 16}

CE203, Innovation and Lean Process Improvement Demystified, Instructors: Jessi Van Der Volgen, AHIP, research assistant librarian, Spencer S. Eccles Health Sciences Library; Erica Lake, associate director, Hope Fox Eccles Health Library; Jean P. Shipman, AHIP, FMLA, director, Spencer S. Eccles
Health Sciences Library; and John Langell;

University of Utah-Salt Lake City

CE204, Knowledge Sharing for Improvement: Hospital Librarians as Knowledge Managers, Instructors: Margo Coletti, AHIP, director, Knowledge Services, Beth Israel Deaconess Medical Center, Boston, MA, and Lorri Zipperer, cybrarian, Zipperer Project Management, Albuquerque, NM

CE301, Advanced Searching Techniques and Advanced Strategy Design, Instructors: Julie Glanville, associate director, York Health Economics Consortium, University of York, York, United Kingdom, and Carol Lefebvre, independent information consultant, Lefebvre Associates, Oxford, United Kingdom

CE302, Health and Wellness @ the Library: The Essentials of Providing Consumer Health Services, Instructor: Kelli Ham, consumer health and technology coordinator, National Network of Libraries of Medicine (NN/LM), Pacific Southwest Region, Louise M. Darling Biomedical Library, Center for the Health Sciences, University of California-Los Angeles

CE303, Bioinformatics for Librarians, Instructor: Natalie Clairoux, librarian, Bibliothèque de la santé, Universite de Montreal, Succursale Centre-ville Montreal, QC, Canada

CE601, Instructional Design: Proven Principles and Practices for Librarians Who Teach, Instructors: Merinda McLure, AHIP, associate professor and health and human sciences librarian, Colorado State University Libraries, Colorado State University-Fort Collins, and Joey Nicholson, education and curriculum librarian, Health Sciences Libraries, New York University School of Medicine-New York

CE703, Introduction to Systematic Reviews for Librarians, Instructors: Susan Fowler, medical librarian coordinator, Systematic Review Services, Becker Memorial Library, Washington University in St. Louis School of Medicine, St. Louis, MO, and Margaret J. Foster, AHIP, systematic reviews and research coordinator and assistant professor, Medical Sciences Library, Texas A\&M University, and joint assistant professor, Department of Health Promotion and Community Health Sciences, School of Public Health, Texas A\&M Health Sciences Center-College Station

CE704, Evidence-Based Medicine (EBM)/ Evidence-Based Practice (EBP): The Basics: Study Design and Randomized Controlled Trials, 
Instructor: Connie Schardt, AHIP, FMLA, adjunct faculty, School of Library and Information Science, University of North Carolina-Chapel Hill

CE705, Evidence-Based Medicine (EBM)/ Evidence-Based Practice (EBP): Beyond the Basics: Systematic Reviews and Qualitative Studies, Instructor: Connie Schardt, AHIP, FMLA, adjunct faculty, School of Library and Information Science, University of North Carolina-Chapel Hill

CE706, Planning, Conducting, and Publishing Library Research, Instructors: Nancy J. Allee, AHIP, deputy director, Taubman Health Sciences Library, University of Michigan-Ann Arbor, and Jo Dorsch, AHIP, FMLA, regional head librarian and professor, Library of the Health Sciences-Peoria, University of Illinois-Chicago, Peoria, IL

\section{Saturday, May 16, 2-hour course options}

CE206, Communicating Information through Visual Design, Instructor: April Aultman Becker, manager, Education, Reference, and Outreach, Research Medical Library, MD Anderson Cancer Center, Houston, TX

CE304, Personalized Genetic Medicine: What Does It Mean?, Instructor: Carrie L. Iwema, AHIP, information specialist, Molecular Biology, Health Sciences Library System, University of Pittsburgh, Pittsburgh, PA

CE400, Perspectives in Research Data Management: An Introduction, Instructors: Alisa Surkis, translational science librarian, and Kevin Read, National Library of Medicine associate fellow, Ehrman Medical Library, New York University School of Medicine-New York

CE401, Perspectives in Research Data Management: A Workshop, Instructors: Alisa Surkis, translational science librarian, and Kevin Read, National Library of Medicine associate fellow, Ehrman Medical Library, New York University School of Medicine-New York

\section{Wednesday, May 20}

CE207, Comparative Effectiveness Research: What? Why? Where? How?, Instructor: Helen-Ann Brown Epstein, AHIP, reference librarian, Sidney Silverman Library, Bergen Community College, Paramus, NJ
CE501, Emerging Technologies for the Busy Librarian, Instructors: Gabriel R. Rios, director, Ruth Lilly Medical Library, Indiana University School of Medicine-Indianapolis, and Melissa De Santis, AHIP, deputy director, Health Sciences Library, Anschutz Medical Campus, University of Colorado-Denver, Aurora, CO

\section{RESOURCES AND SERVICES}

Staffed by the Local Assistance Committee, the Hospitality Center provided maps and information about local attractions in Austin. Members of the 2015 National Program Committee, Local Assistance Committee, and volunteer bloggers all contributed to the official meeting blog with announcements, meeting tips, information on papers and posters, section programming, and more. Live streaming conversations were available on Twitter at hashtag \#mlanet15. The Internet Café offered wireless access for meeting attendees, and complimentary WiFi was available throughout the convention center. A Member Resource Room was also available with a photocopier, computers, and a laser printer. For those seeking new jobs and prospective employers, the Job Placement Center was open from Saturday through Tuesday. In conjunction with the Job Placement Center, the Professional Recruitment and Retention Committee sponsored a Resume Clinic to review cover letters, resumes, and CVs for attendees during Job Placement Center hours, Saturday through Tuesday. Sponsored by McGraw-Hill Medical, the Relaxation Station offered attendees a seated chair massage to ease their meeting stress. The MLA Connections Booth offered attendees the opportunity to donate to the MLA grants and scholarships program. The Hall of Exhibits was open Saturday through Tuesday and included a booth for the 2016 Joint MLA/CHLA/ABSC/ICLC Meeting in Toronto.

\section{AUTHOR'S AFFILIATION}

Nicole Mitchell, MLIS, MA, nmitchell@ acomedu.org, Proceedings Editor and Information Technology Librarian and Associate Professor, Alabama College of Osteopathic Medicine, 445 Health Sciences Boulevard, Dothan, AL 36303 